\title{
Factors Affecting Turnover as Perceived by County Agents who Voluntarily Left the West Virginia University Extension Service
}

\author{
Michael B. Withrow
}

Follow this and additional works at: https://researchrepository.wvu.edu/etd

\section{Recommended Citation}

Withrow, Michael B., "Factors Affecting Turnover as Perceived by County Agents who Voluntarily Left the West Virginia University Extension Service" (2015). Graduate Theses, Dissertations, and Problem Reports. 6965.

https://researchrepository.wvu.edu/etd/6965

This Thesis is protected by copyright and/or related rights. It has been brought to you by the The Research Repository @ WVU with permission from the rights-holder(s). You are free to use this Thesis in any way that is permitted by the copyright and related rights legislation that applies to your use. For other uses you must obtain permission from the rights-holder(s) directly, unless additional rights are indicated by a Creative Commons license in the record and/ or on the work itself. This Thesis has been accepted for inclusion in WVU Graduate Theses, Dissertations, and Problem Reports collection by an authorized administrator of The Research Repository @ WVU. For more information, please contact researchrepository@mail.wvu.edu. 
Factors Affecting Turnover as Perceived by County Agents who Voluntarily Left the West Virginia University Extension Service

\title{
Michael B. Withrow
}

Thesis submitted to the Davis College of Agriculture, Natural Resources and Design at West Virginia University in partial fulfillment of the requirements for the degree of

\author{
Master of Science \\ in \\ Agricultural and Extension Education
}

Deborah A. Boone, Ph. D., Chair

Harry N. Boone, Jr., Ph.D.

Jean M. Woloshuk, Ed.D.

School of Design and Community Development

Morgantown, West Virginia

2015

Keywords: Turnover, Extension Service, Voluntarily Leaving 
Factors Affecting Turnover as Perceived by County Agents who Voluntarily Left the West Virginia University Extension Service

\author{
Michael B. Withrow
}

\begin{abstract}
This descriptive survey study sought to identify factors that influenced West Virginia University County Extension Agents to voluntarily leave the organization. The population consisted of 31 individuals who had left the Extension Service from 20092014. A survey which was composed of four main question sets was mailed to the identified population.
\end{abstract}

Questions focused on the constructs of organizational factors, job related factors, personal factors, and demographics. Data were collected and analyzed to identify contributing factors in each of the constructs. The study found that a major factor that contributes to agents leaving Extension was having other priorities in the individuals' life. A key factor that was also identified was the ability to maintain personal relationships. The amount of work required of an agent leaves little time for family, friends, and personal social lives.

Several remarks noted in response to the open ended questions stated if the amount of time spent during nights, weekends, and summers were reduced, then they would have stayed employed with the West Virginia University Extension Service. Identification of factors which impact agents to leave will help administration of the West Virginia University Extension Service to develop programs and training that will help retain agents. 


\section{ACKNOWLEDGEMENTS}

My journey through graduate school has had many blessings in it. Thank you to everyone who has been there to push me forward in this endeavor. First, a sincere thank you to Dr. Deborah Boone, my fearless chair. She always provided an immense amount of great support, and always had an ear to listen. Dr. Boone was always ready with feedback, a word of encouragement, or a reminder to take time to sleep. Her outlook on life was extremely helpful in guiding my graduate school process.

Thank you to my other committee members Dr. Harry Boone, and Dr. Jean Woloshuk. Dr. Harry always had encouraging words, even when asked the most random questions. Believe me, they were almost all random. Jean provided an immense amount of knowledge about the workings of Extension. It was truly an honor to work with her. I am extremely grateful for the whole Agricultural and Extension Education faculty. Dr. Stacy Gartin and Dr. Jessica Blythe were always ready to hear my latest problem, solution, or smallest victory.

The completion of my graduate study is a direct product of the support from my friends and family. Many memories were made in the graduate student office. Between Entomology, Panera, and the random trips to get groceries, there were so many times to be had. A special thank you goes out to Lauren Daub-Devine, Dylan Johnson, Dawn McKenzie, and the rest of my fellow graduate students. Thank you to my roommates, Colter Taylor and Zach Winfield, for helping me to survive the whole process of going through school. They were understanding and helpful whenever I would carry my work home with me. Many memories were made, and even more times are to be had! 
To my family, blood related or not, thank you for pushing me to always reach farther, and dream bigger. It was amazing to have the support of so many individuals who truly care about my future. Although my biggest supporter will not see me graduate, Pappy was my biggest motivator to come back to school. He always told me, "You don't always have to be the best, as long as you do your best." I will forever be grateful for the passion he instilled in me for agriculture, and try to live up to his efforts to help others. Graduate school was not always easy, but the help from the amazing people who supported me has paid dividends. I hope that one day I am able to help others in the ways that people have helped me. 


\section{TABLE OF CONTENTS}

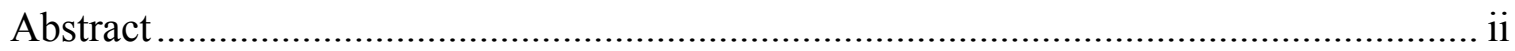

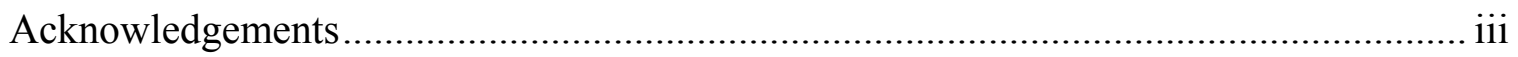

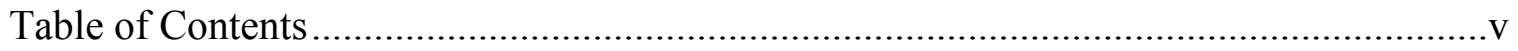

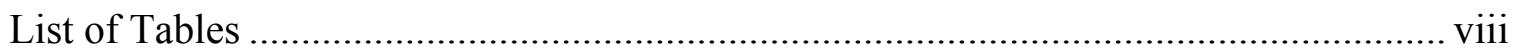

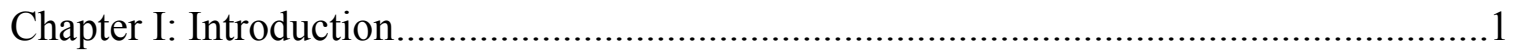

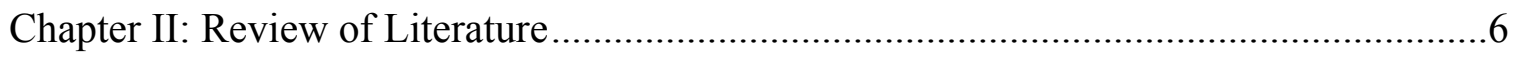

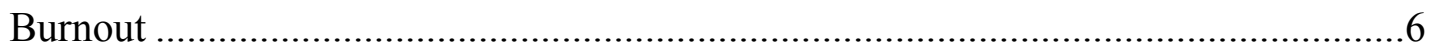

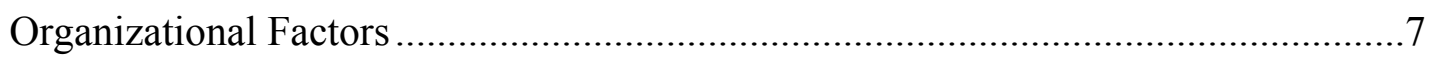

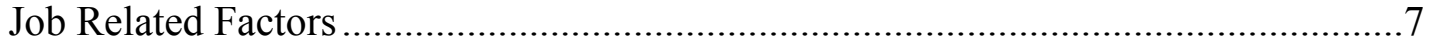

Non-work Related Factors ..............................................................................

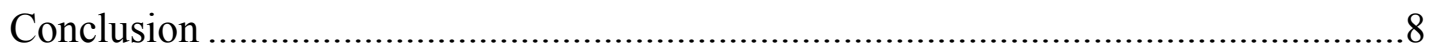

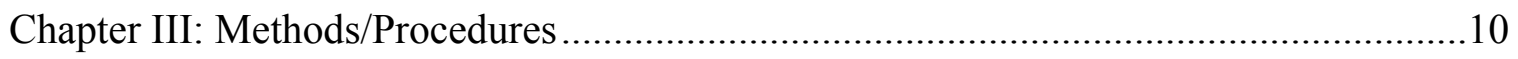

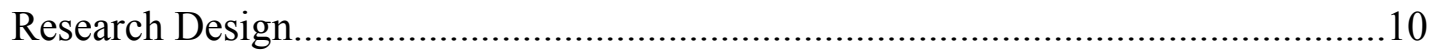

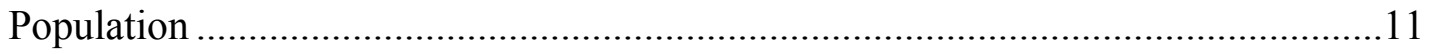

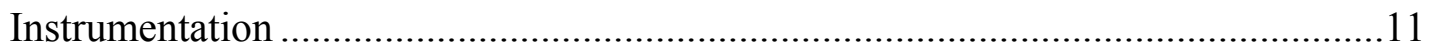

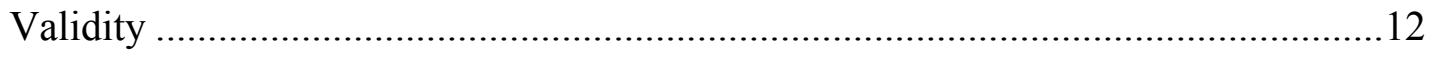

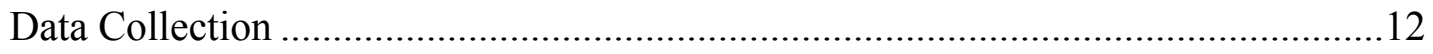

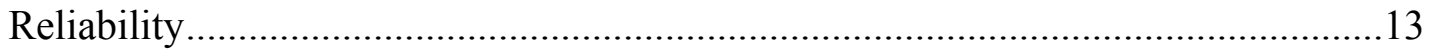

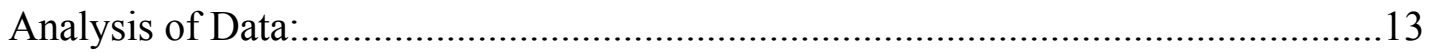


Use of Findings

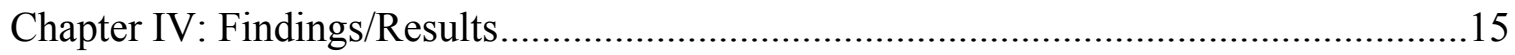

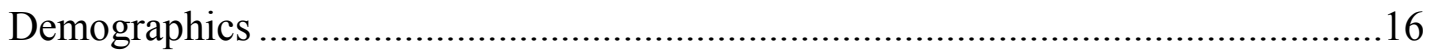

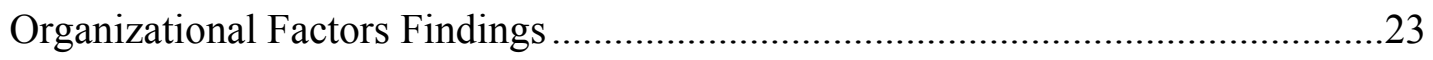

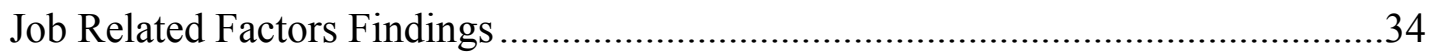

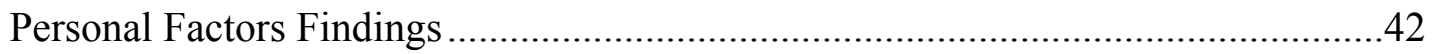

Chapter V: Conclusions/Recommendations/Implications ..............................................52

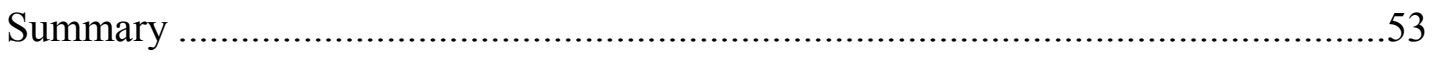

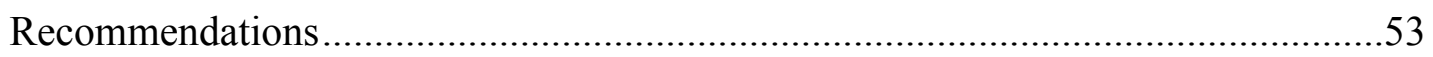

Recommendations for Further Study ................................................................54

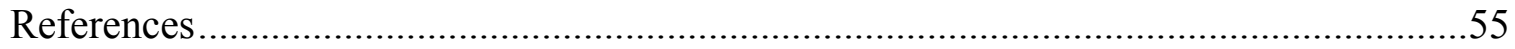

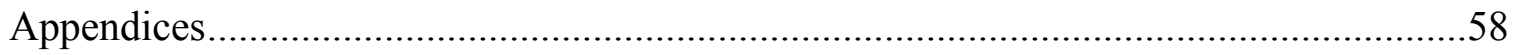

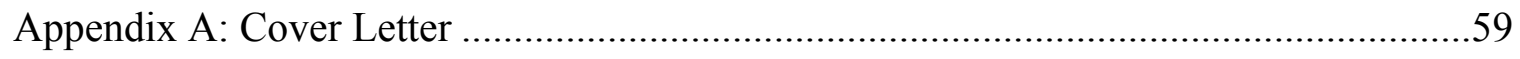

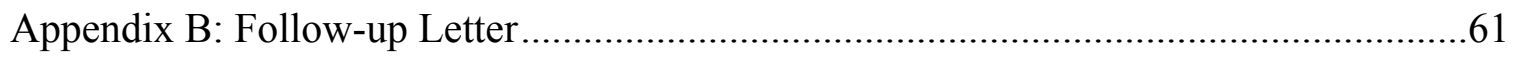

Appendix C: Comments to Organizational Factors ............................................................63

Appendix D: Comments to Job Related Factors ............................................................66

Appendix E: Comments in Personal Factors ...............................................................68

Appendix F: Comments on Main Reason for Leaving ..................................................70

Appendix G: Responses to What Could Have Prevented Agents From Leaving? .............72

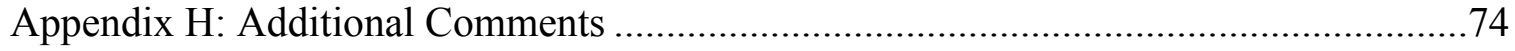




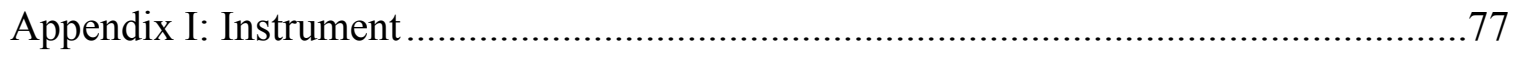

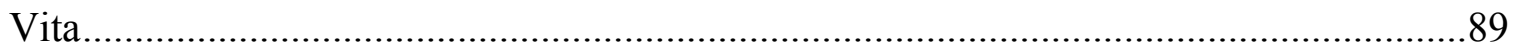




\section{LIST OF TABLES}

Table 1 Construct Reliabilities.

Table 2 Were Respondents Native to West Virginia ............................................16

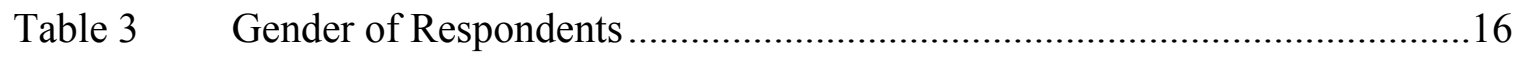

Table $4 \quad$ Age at Time of Leaving Extension ..................................................... 17

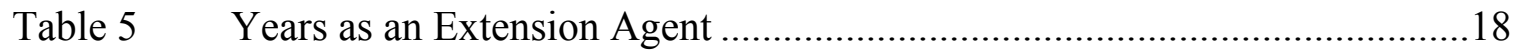

Table $6 \quad$ Area of Extension Employed ........................................................... 19

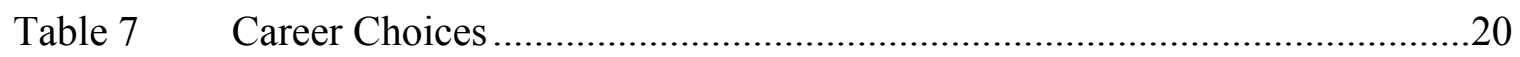

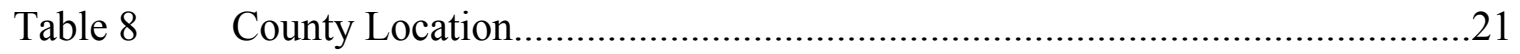

Table 9 Relationship Status When Left Extension ...........................................22

Table 10 Number of Children in Household When Left Extension ...........................22

Table 11 Organizational Factors that Influenced the Decision to Leave Extension....30

Table 12 Job Related Factors Influencing Turnover.............................................39

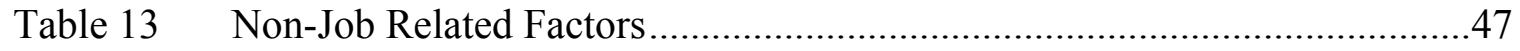

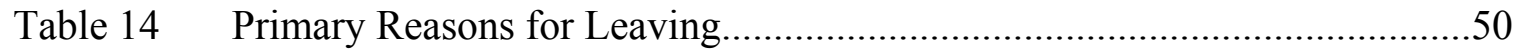

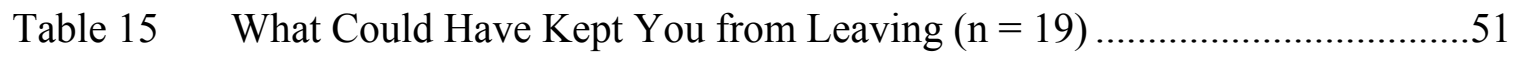




\section{CHAPTER I}

\section{Introduction}

West Virginia University Extension Service has a presence in each of the state's 55 counties. There are approximately 450 positions within the West Virginia University Extension Service (WVUES) (West Virginia University Extension Service, 2014).

According to S. Bonano, WVUES Interim Director; "We currently see around 10 percent loss of faculty Extension Agents yearly" (personal communication on September 16, 2014). Therefore, turnover should be a concern of the Extension Administrators. Turnover can be defined as, "the cessation of membership in an organization by an individual who received monetary compensation from the organization" (Mobley, 1982, p. 10). Turnover in organizations has been the subject of much research and has been theorized since the 1900's (Mowday, 1981). The primary resource of the Extension Service is its staff and volunteers (Kulitek, 2000). Therefore, one must understand the reasons why turnover is occurring within the organization.

West Virginia University Extension Agents are assigned to one of four program units (West Virginia University Extension, 2011). These programs include: 4-H and Youth Development; Agriculture and Natural Resources; Families and Health; and Community, Economic and Workforce Development. Rousan (1995) identified home economics, agriculture education, animal science, general agriculture, education, agronomy, and business as the major degrees that contribute to the extension field. Each degree is openly accepted based on the program type that is vacant (K. Suder, personal communication September 29, 2014). "The fit of the position to participants' lifestyle and background was ultimately determined by the advertised position description" (Arnold \& 
Place, 2010, p. 4). The position offered should be applicable to the applicants' personal and professional interests, thus motivating applicants to seek employment (Arnold \& Place 2010).

Extension educational programs are tailored to address the needs of the participants (Fetsch \& Kennington 1997). Rousan and Henderson (1996) found that the amount of work and effort put into developing and implementing numerous programs increases the agent's overall workload, and is one of their major reasons for leaving. The factors of time commitment and reporting have been researched extensively (Arnold, 2007; Carter, 1989; Mowbray, 2002). The work demands of Extension require additional hours outside of the typical work day (Fetsch, Flashman, \& Jeffers 1984). These restrictions apply stress to agents' personal activities (Clark, 1992; Ensle, 2005; Igoden \& Newcomb, 1986)

Although no formal research on West Virginia University Extension turnover factors have been reported, multiple other states have examined reasons why agents voluntarily leave. Carter (1989) researched factors related to turnover in Louisiana, while Rousan (1995) studied Extension Agent turnover in Ohio. Although the studies were conducted six years apart and are in two different states, their findings were similar. Both have reported that numerous personal repercussions stem from the rigorous demand on the pace of the agents' careers (Carter, 1989; Rousan, 1995) A number of studies identified four common categories of factors that impact agents decisions to leave the Extension employment which include: organizational factors, individual work factors, individual non-work factors, and personal influences (Arnold, 2007; Carter, 1989; Mowbray, 2002; Rousan, 1995). 
Job satisfaction has been reported as a key factor when considering leaving the Extension Service (Arnold, 2007; Mowbray, 2002; Riggs \& Beus, 1991; Rousan, 1995). Research has shown that dissatisfied agents leave their positions, while satisfied agents stay employed for an extended period of time (Arnold 2007). When looking at job satisfaction, Riggs and Beus (1993) identified the six characteristics of positive satisfaction as: job, salary, benefit, program authority, supervisors, growth opportunities, the organization, and colleagues. Johnson (1992) found negative factors to include: salary, budget, supervision strategies, policy, environment, and administration.

\section{Problem Statement}

Extension has had a long tradition of agents forming a community bond within their job. Agents are at the forefront when it comes to establishing practices that researchers from the land grant institutions report (Arnold, 2007). Agents must have the abilities to not only educate the clientele, but must do so utilizing practical applications which met the needs and common interests of the community (Arnold \& Place, 2010). The individuals who become agents must apply their personal talents to excel in this field. As an agency based off of the needs of the public, anytime there is a lapse in time without an agent, problems could potentially arise (Rousan, 1995). With retention being a primary concern for many organizations, we must understand the factors as to why agents are voluntarily leaving the organization.

\section{Theoretical Framework}

The clusters of skills, abilities, and other characteristics model by Hahn (1979) was used to guide this study. This model divides certain aspects of being a successful agent into seven primary clusters with overlap occurring. The sections of this model show 
how independently they are able to be observed, as well as how collaboratively they interact within each other to form a whole. The seven clusters are in order as follows: commitment to the job, communication skills, interpersonal skills, positive attitude, program development and direction, problem solving, and self-confidence. Many of these categories can be observed on various applications for Extension positions throughout the organization.

\section{Purpose of Study}

The purpose of this study was to determine the key factors that were causing turnover rates in the West Virginia University Extension Service (WVUES) to remain at an elevated level. This information will be useful to the administration and human resource divisions of the WVUES. Outcomes of this study can be used to identify key retention factors, as well as provide information relevant to the recruitment of new individuals.

\section{Objectives}

The objectives of this study were reflected in the following research questions:

1. What job related factors and experiences impacted Extension Agents' decisions to leave the organization?

2. What organizational factors impacted Extension Agents' decisions to leave the organization?

3. What personal factors and experiences influenced Extension Agents' decisions to leave the organization?

4. Describe the characteristics of Extension Agents who voluntarily leave the organization. 
5. Determine the most significant factors that influence agents to leave the WVUES.

\section{Limitations of Study}

One limitation of this study was the number of years since agents left WVUES. This study was limited to agents who left WVUES within the past five years. 


\section{CHAPTER II}

\section{Review of Literature}

\section{Burnout}

During the time an agent voluntarily leaves the organization, there is a definite interruption in the Extension services programming and an impact on the county they left (Rousan \& Henderson, 1996). Turnover in Extension Agents comes with a cost. It has been calculated that it costs the service nearly $\$ 80,000$ to completely turnover one single agent (Kutilek, 2000). Many times when agents explain why they leave, they lump all reasons together into the burnout stage of the career. Many seem to experience the burnout effects in their mid-20s to early 30s (Igodan \& Newcomb, 1986). Burnout is the process of mentally and physical draining the body (Ensle, 2005; Igodan \& Newcomb, 1986). Agents work schedules are very demanding. Agents are often seen working long days and extended hours on weekends (Fetsch, Flashman, \& Jeffiers, 1984).

Although the factors of turnover vary from region to region, all involve various aspects related to the job as well as personal matters (Arnold, 2007; Carter, 1989; Mowbray, 2002; Rousan, 1995). Many studies focus on agents, however, Clark (1992) looked at the directors of Extension. Although these are different positions, both experience similar reactions to turnover. The concern over the resignation has developed many ideas and theories as to why folks leave (Manton \& van Es, 1985). The commonalities of voluntary turnover often include job satisfaction, job involvement, and organizational impact (Lee \& Mowday, 1987). 


\section{Organizational Factors}

A key way to solve turnover problems is to evaluate the amount of stress the individuals must deal with in the organization (Fetsch \& Kennington, 1997). An important key factor of voluntary turnover is the lack of recognition (Harder, Gouldthorpe, \& Goodwin, 2014; Rousan, 1995). Rousan (1995) found that more than $75 \%$ of the respondents did not leave the organization due to early retirement, a lack of in-service trainings, or inadequate benefits. The research found respondents scored insufficient pay for amount of work, too many work responsibilities, and lack of recognition as being things that "Definitely" or "Greatly" influenced them to leave. Mowbray (2002) had similar findings to Rousan, noting that insufficient pay, amount of work expected and lack of recognition were major factors that influenced the agents to leave the Kentucky Extension Service.

\section{Job Related Factors}

Rousan's (1995) study included many organizational factors. One of the major organizational factors reported as being a problem was the amount of excessive time and effort that agents are required to work. Many individuals link job satisfaction and job performance to the turnover of the individual in the job (Bouckennooghe, Raja, \& Butt, 2013.) Rousan (1995) found that having other priorities in life, too many late night meetings, and conflicting personal and work values as the key job related factors that caused agents to voluntarily leave. Mowbray (2002) found that agents left for similar reasons including too many night, weekend, or overnight commitments, followed closely by having other priorities in life. 


\section{Non-work Related Factors}

Rousan (1995) found that certain demographics can be separated out for a large group of agents that have left. Rousan's (1995) findings support the positon of Watts \& White (1988) that the age of the employee is a factor. Younger employees with shorter tenure cycles are more likely to leave. Agents often pursue careers in Extension due to their background or experiences (Arnold \& Place, 2010). Major reasons related to personal matters influencing agents to leave involve their families (Fetsch \& Kennington, 1997). Watts \& White (1988) found that no consistencies occur between turnover and intelligence, level of education, or gender of the individuals.

Rousan (1995) noted that one major item that was not a factor that caused agents to leave was leaving for other members of their families, however family obligations was a key influencing factor. Rousan (1995) found that more money elsewhere and work conflicting with personal responsibilities were a few of the major factors which impacted the population to leave. Rousan (1995) found that nearly one-fourth of the population in the study wanted a career change or had another job offer. The same study noted excessive time and job requirements to be a major reason why agents left. Mowbray (2002) found family obligations, a desire to spend more time with family, more money elsewhere, and work conflicts with other personal responsibilities as the top five factors that influenced agents to leave.

\section{Conclusion}

Agents who stay are those who are highly satisfied with their job (Riggs \& Beus, 1993). Hom \& Kinicki in 2001 analyzed how to better understand how dissatisfaction progressively moves employee turnover. Rousan (1995) found that part of the population 
polled, noted that they wanted a career change or had another job offer. Rousan (1995) also noted the participants linked the excessive time and job requirements as a major reason why they left. 


\section{CHAPTER III \\ Methods/Procedures}

\section{Purpose of Study}

The purpose of this study was to determine the key factors that were causing turnover rates in the West Virginia University Extension Service (WVUES) to remain at an elevated level. This information will be useful to the administration and human resource divisions of the WVUES. Outcomes of this study can be used to identify key retention factors, as well as provide information relevant to the recruitment of new individuals.

\section{Objectives}

The objectives of this study were reflected in the following research questions:

1. What job related factors and experiences impacted Extension Agents' decisions to leave the organization?

2. What organizational factors impacted Extension Agents' decisions to leave the organization?

3. What personal factors and experiences influenced Extension Agents' decisions to leave the organization?

4. Describe the characteristics of Extension Agents who voluntarily leave the organization.

5. Determine the most significant factors that influence agents to leave the WVUES.

\section{Research Design}

A descriptive research design was used for this study. Using this type of research

allows researchers to provide in depth, descriptive details that pertain to the knowledge of 
the respondents. Descriptive research is often used in the social sciences (psychology, sociology, education, etc.) to include the observation of subjects' reactions. Descriptive research can be achieved through the implementation of mailed questionnaires. In general, there is a higher number of mailed surveys annually, than any other research based study (Dillman, 1991).

Data were collected using a mailed questionnaire in a double blind study. The West Virginia University Extension Service Director of Human Resources maintained the list of names and addresses of those agents who had voluntarily left county agent positions. Packets containing a cover letter, survey and coded postage paid response envelopes were taken to the WVUES Director of Human Resources, who applied mailing labels and recorded the participant code and put packets in the mail. Return packets were addressed to the researchers, so responses were not returned directly to the Director of Human Resources. The participant codes were used only for the purpose of contacting non-respondents.

\section{Population}

The population for this study included the 31 WVUES agents who had voluntarily left the Extension Service from January 1, 2009 through October 1, 2014. An official list of Extension Agents maintained by the Human Resources department of the WVUES was used for this study.

\section{Instrumentation}

A mailed survey was the best method to reach the target population which was located across the state of West Virginia. The survey consisted primarily of Likert scale items to determine common factors of why Extension Agents left employment with the 
WVUES. Additional spaces were provided so respondents could explain why they marked any answer at the highest or lowest level of agreement. This allowed the audience to provide explainable, variable feedback on selected topics. A section was also included to collect demographical information.

\section{Validity}

The instrument was presented to a panel of experts for review. The panel consisted of professors from Agriculture and Extension Education and a retired Extension specialist. Each member of the panel had extensive teaching, research and Extension experience. The panel determined that the instrument had content and face validity.

\section{Data Collection}

The coded survey was mailed to previous WVUES employees who voluntarily left a county position. The initial packet included a cover letter (see Appendix A), questionnaire (see Appendix B), return envelope, and sheet to sign up for a drawing of a Wal-Mart gift card as an incentive to participate. The cover letter explained the purpose of the study and how their participation was essential to the outcome of the study. The first packet was sent out on January 5, 2015 with a request that the survey be returned by January 16, 2015. A follow up mailing was sent out on January 26, 2015 with a response date of February 6, 2015. Data were compiled in an Excel spreadsheet for analysis on February 13, 2015. There were 31 individuals in the initial population that received surveys. Nineteen individuals responded to the questionnaire for a response rate of $61.2 \%$. T-tests were run on the constructs to compare early and late respondents. When comparing the two categories, no differences were found on the constructs. Although 
generalizations could be made to the entire population, the findings of this study were limited to respondents.

\section{Reliability}

A split half was calculated to determine overall reliability of the instrument, which resulted in a Spearman Brown reliability coefficient of .780. According to Robinson, Shaver, \& Wrightsman it was found to have exemplary reliability. The Likert questions were then compiled into constructs representing organizational factors, job related factors, and personal factors. A Cronbach's alpha was then run independently for each construct. The Cronbach's alpha for organizational factors, job related factors, and personal factors were found to be $.890, .861$, and .806 , respectfully. According to Robinson, Shaver, \& Wrightsman (1991) they were all found to have exemplary reliability (see Table 1).

Table 1

Construct Reliabilities

\begin{tabular}{lcc}
\hline & Cronbach's Alpha & Reliability Scale $^{1}$ \\
\hline Organizational Factors & .890 & Exemplary \\
Job Related Factors & .861 & Exemplary \\
Personal Factors & .806 & Exemplary \\
\hline
\end{tabular}

${ }^{1}$ Robinson, Shaver, \& Wrightsman, 1991

\section{Analysis of Data:}

Data were analyzed utilizing the SPSS 22.0 for Windows. The level of significance was set $a$ priori at $\alpha \leq .05$ for all statistical tests. Descriptive analyses appropriate for the respective scales of measurement were performed on the data including measures of central tendency (mean, median, or mode) and variability 
(frequencies or standard deviation). The results were represented as frequencies and percentages as well as mean, median and mode in both table and narrative form.

\section{Use of Findings}

The use of findings will be utilized by the Human Resource Professionals of WVUES to provide an understanding of how to effectively recruit and retain Extension Agents. From a functional analysis perspective utilization of these findings offers insights into the recruitment, retention and placement of service workers (Clary et al., 1992). 


\section{CHAPTER IV}

\section{Findings/Results}

\section{Purpose of Study}

The purpose of this study was to determine the key factors that were causing turnover rates in the West Virginia University Extension Service (WVUES) to remain at an elevated level. This information will be useful to the administration and human resource divisions of the WVUES. Outcomes of this study can be used to identify key retention factors, as well as provide information relevant to the recruitment of new individuals.

\section{Objectives}

The objectives of this study were reflected in the following research questions:

1. What job related factors and experiences impacted Extension Agents' decision to leave the organization?

2. What organizational factors impacted Extension Agents' decision to leave the organization?

3. What personal factors and experiences influenced Extension Agents' decision to leave the organization?

4. Describe the characteristics of Extension Agents who voluntarily leave the organization.

5. Determine the most significant factors that influence Extension Agents to leave the WVUES. 


\section{Demographics}

The population of this study was asked to indicate whether or not they were a native of West Virginia. Fourteen (73.68\%) indicated that they were natives of the state. Five $(26.32 \%)$ reported that they were not natives of West Virginia. There were 19 responses to this question (see Table 2).

Table 2

Were Respondents Native to West Virginia?

\begin{tabular}{lcc}
\hline & $\mathrm{N}$ & $\%$ \\
\hline Yes & 14 & 73.68 \\
No & 5 & 26.32 \\
\hline
\end{tabular}

The respondents were asked to indicate their gender. Of the population, 13 $(68.42 \%)$ reported they were female. Six individuals $(31.58 \%)$ indicated they were male. There were a total of 19 responses to the question (see Table 3).

Table 3

Gender of Respondents

\begin{tabular}{lcc}
\hline & $\mathrm{N}$ & $\%$ \\
\hline Female & 13 & 68.42 \\
Male & 6 & 31.58 \\
\hline
\end{tabular}

The population was asked to indicate their age when leaving the Extension Service by selecting a category from the ordinal scale provided. One individual $(5.3 \%)$ indicated they were in the 20-24 year old age group, while one individual (5.3\%) reported they were 25-29 years of age and another individual (5.3\%) responded they were 30-34 
years old. One individual (5.3\%) reported their age to be in the 35-39 year old age group, while two $(10.5 \%)$ respondents indicated they were $40-44$ years old. Two individuals $(10.5 \%)$ reported they were $45-49$ years old while no respondents were in the 50-54 year old group. Three individuals (15.8\%) responded that they were 55-59 years old and eight respondents (42.1\%) indicated they were 60 plus years of age. There were a total of 19 responses (see Table 4).

Table 4

Age at Time of Leaving Extension

\begin{tabular}{lcc}
\hline & $\mathrm{N}$ & $\%$ \\
\hline $20-24$ years & 1 & 5.26 \\
$25-29$ years & 1 & 5.26 \\
$30-34$ years & 1 & 5.26 \\
$35-39$ years & 1 & 5.26 \\
$40-44$ years & 2 & 10.53 \\
$45-49$ years & 2 & 10.53 \\
$50-54$ years & 0 & 0.00 \\
$55-59$ years & 3 & 15.79 \\
$60+$ years & 8 & 42.11 \\
\hline
\end{tabular}

The population was asked to indicate the number of years they served in a county agent position. Four individuals $(21.1 \%)$ indicated that they were in an agent's role for 0 2 years, while four $(21.1 \%)$ individuals reported they had been an agent for 3-5 years. One respondent (5.3\%) indicated that they were an agent for 6-8 years. There were no individual respondents who were reported 9-11 years of service. Ten respondents 
$(52.6 \%)$ indicated that they were in their positions for $12+$ years. There were 19 responses to this question (see Table 5).

Table 5

Years as an Extension Agent

\begin{tabular}{lcc}
\hline & $\mathrm{N}$ & $\%$ \\
\hline $0-2$ years & 4 & 21.05 \\
$3-5$ years & 4 & 21.05 \\
6-8 years & 1 & 5.26 \\
$9-11$ years & 0 & 0.00 \\
$12+$ years & 10 & 52.63 \\
\hline
\end{tabular}

The respondents were asked to indicate in which program area they worked. Six individuals (31.6\%) reported Agriculture and Natural Resource as their primary program area. Four of the respondents (21.1\%) indicated Community, Economic, and Workforce Development as the program in which they worked. There were three individuals (15.8\%) whose job fell under the Families and Health program unit. Six individuals (31.6\%) reported 4-H and Youth Development as their primary program of work. There were 19 responses to this question (see Table 6). 
Table 6

Area of Extension Employed

\begin{tabular}{lcc}
\hline & $\mathrm{N}$ & $\%$ \\
\hline Agriculture and Natural Resource & 6 & 31.58 \\
$\begin{array}{l}\text { Community Economic Workforce } \\
\text { Development }\end{array}$ & 4 & 21.05 \\
Families and Health & 3 & 15.79 \\
4-H and Youth Development & 6 & 31.58 \\
Other & 0 & 0.00 \\
\hline
\end{tabular}

The questionnaire included two questions about career choices regarding Extension positions. When asked if Extension was their first full time job out of college, four respondents $(21.05 \%)$ reported that it was their first job. Fifteen individuals (79.95\%) indicated that Extension was not their first job. The second question asked if Extension was their first career choice. Six individuals $(31.58 \%)$ indicated that Extension was their first career choice. Thirteen individuals (68.42\%) reported that Extension was not their first career choice. There were 19 responses to each of these questions (see Table 7). 
Table 7

Career Choices

\begin{tabular}{lcccc}
\hline & \multicolumn{2}{c}{ Yes } & \multicolumn{2}{c}{ No } \\
\cline { 2 - 5 } & $\mathrm{N}$ & $\%$ & $\mathrm{~N}$ & $\%$ \\
\hline $\begin{array}{l}\text { Extension First Full Time Job } \\
\text { Out Of College }\end{array}$ & 4 & 21.05 & 15 & 78.95 \\
$\begin{array}{l}\text { Extension Was First Career } \\
\text { Choice }\end{array}$ & 6 & 31.58 & 13 & 68.42 \\
\hline
\end{tabular}

The respondents were asked to select an area of counties in which they served during their time as an Extension Agent. The counties were grouped together based off of their geographical location to one another. The area consisting of Pendleton, Grant, Hardy, Mineral, Hampshire, Morgan, Berkeley, and Jefferson Counties had six respondents $(31.58 \%)$ who indicated they were from this region. The region consisting of Randolph, Tucker, Preston, Monongalia, Marion, Taylor, Barbour, Upshur counties had three individuals (15.79\%) indicated they were from this area. In the area of Hancock, Brooke, Ohio, Marshall, Wetzel, Tyler, Doddridge, and Harrison counties, three individuals (15.79\%) indicated that they served this area. Two individuals $(10.53 \%)$ reported that they were from the area which included Pleasants, Wood, Ritchie, Jackson, Wirt, Roane, Calhoun, Gilmer, or Lewis County. The options of Mason, Cabell, Putnam, Kanawha, Wayne, Lincoln, and Boone counties had four individuals (21.1\%) who indicated that they served in this area. For the counties of Braxton, Clay, Nicolas, Webster, Pocahontas, Fayette, and Greenbrier there were no respondents from these counties. One individual $(5.3 \%)$ indicated that they served in the area represented by the counties of Mingo, Logan, Wyoming, McDowell, Mercer, Raleigh, Summers, and 
Monroe. There were 19 responses to the question regarding location of where they served (see Table 8).

Table 8

County Location of Service

\begin{tabular}{llc}
\hline & $\mathrm{N}$ & $\%$ \\
\hline $\begin{array}{l}\text { Pendleton, Grant, Hardy, Mineral, Hampshire, } \\
\text { Morgan, Berkeley, Jefferson }\end{array}$ & 6 & 31.58 \\
$\begin{array}{l}\text { Randolph, Tucker, Preston, Monongalia, } \\
\text { Marion, Taylor, Barbour, Upshur }\end{array}$ & 3 & 15.79 \\
$\begin{array}{l}\text { Hancock, Brooke, Ohio, Marshall. Wetzel, } \\
\text { Tyler, Doddridge, Harrison }\end{array}$ & 3 & 15.79 \\
$\begin{array}{l}\text { Pleasants, Wood, Ritchie, Jackson, Wirt, } \\
\text { Roane, Calhoun, Gilmer, Lewis }\end{array}$ & 2 & 10.53 \\
$\begin{array}{l}\text { Mason, Cabell, Putnam, Kanawha, Wayne, } \\
\text { Lincoln, Boone }\end{array}$ & 4 & 21.05 \\
$\begin{array}{l}\text { Braxton, Clay, Nicolas, Webster, Pocahontas, } \\
\text { Fayette, Greenbrier }\end{array}$ & 0 & 0.00 \\
$\begin{array}{l}\text { Mingo, Logan, Wyoming, McDowell, Mercer, } \\
\text { Raleigh, Summers, Monroe }\end{array}$ & 1 & 5.23 \\
\hline
\end{tabular}

The respondents were asked to indicate their relationship status when they left the Extension Service. Two individuals (10.53\%) responded that they were single and one respondent (5.26\%) reported being in a committed relationship. Sixteen respondents (84.21\%) indicated that they were married when leaving the Extension Service. No respondents reported they were divorced. There were 19 responses to the survey (see Table 9). 
Table 9

Relationship Status When Left Extension

\begin{tabular}{lcc}
\hline & $\mathrm{N}$ & $\%$ \\
\hline Single & 2 & 10.53 \\
In a committed relationship & 1 & 5.26 \\
Married & 16 & 84.21 \\
Divorced & 0 & 0.00 \\
\hline
\end{tabular}

The respondents were asked to indicate how many children were in their household at the time of leaving Extension. Fourteen individuals (73.68) responded that they had zero children in their home. Five individuals $(26.32 \%)$ reported having $1-2$ children at the time. No respondents indicated having three or more children in their households. There were 19 responses to this question (see Table 10).

Table 10

Number of Children in Household When Left Extension

\begin{tabular}{lcc}
\hline & $\mathrm{N}$ & $\%$ \\
\hline 0 children & 14 & 73.68 \\
$1-2$ children & 5 & 26.32 \\
$3-4$ children & 0 & 0.00 \\
$5+$ children & 0 & 0.00 \\
\hline
\end{tabular}

The participants were asked to respond to three different sets of questions. The sections represented organizational factors, job related factors, and personal factors that may have influenced agents to leave the Extension Service. Respondents were asked to 
rate the items on a Likert type scale ranging from "Definitely Did Not Influence," to "Definitely Did Influence"” "Definitely Did Not Influence" was indicated on the survey as "DNI" and recorded as a 1 in the dataset. "Very Little Influence" was marked as "VLI" and was recorded as a 2 in the data set. "Somewhat Influenced" was offered as "SI" and counted as a 3 for data interpretation. "Greatly Influenced" was indicated as "GI" and recorded as a 4. "Definitely Did Influence" was indicated by using "DI" and registered as a 5 for data purposes.

\section{Organizational Factors Findings}

The participants were asked to respond to 21 question regarding "Organizational Factors" that may have influenced agents to leave. There were 19 respondents per question, unless otherwise stated.

When asked if little opportunity for advancement influenced their departure, 12 individuals (63.16\%) stated that it "Definitely Did Not Influence" their decision. Three individuals (15.79\%) stated that it had "Very Little Influence," three (15.79\%) selected that it "Somewhat Influenced" them, and one individual (5.26\%) selected that it "Greatly Influenced" their departure. No respondents marked that it "Definitely Did Influence" their decision to leave the service (see Table 11).

When asked if the amount of work expected was a factor, eight respondents (42.11\%) stated that it "Definitely Did Not Influence" them to leave. Three individuals (15.79\%) said it had "Very Little Influence." Three (15.79\%) respondent reported that it "Somewhat Influenced," one respondent (5.26\%) indicated that it "Greatly Influenced," and four (21.05\%) said that it "Definitely Did Influence" their decisions to leave (see Table 11). 
When asked if the amount of repetitive work influenced them to leave, 17 respondents (89.47\%) stated that it "Definitely Did Not Influence" their decisions to leave. One individual (5.26\%) stated that it had "Very Little Influence." There were no respondents who indicated the amount of repetitive work had "Somewhat Influenced" or "Greatly Influenced" their decisions to leave. One respondent (5.26\%) reported that it "Definitely Did Influence" them to leave the Extension Service (see Table 11).

When asked if they had an inadequate office space that caused them to leave the Extension Service, 13 individuals (68.42\%) indicated that it "Definitely Did Not Influence" them. Three individuals (15.79\%) reported that it had "Very Little Influence," while two individuals (10.53\%) indicated that it "Somewhat Influenced" and one individual (5.26\%) reported that it "Greatly Influenced" their decision to leave. No respondents responded that it "Definitely Did Influence" them to leave the Extension Service (see Table 11).

When asked if having an insufficient number of support staff was a factor when leaving, 12 individuals (63.16\%) reported it "Definitely Did Not" have an influence. One individual (5.26\%) indicated that it had "Very Little Influence," and two (10.53\%) reported that they were "Somewhat Influenced" by insufficient of support staff. Two individuals (10.53\%) responded that insufficient support staff "Greatly Influenced" their decision, while two respondents $(10.53 \%)$ reported that it "Definitely Did Influence" their leaving (see Table 11).

When asked if lack of up-to-date equipment was a factor in leaving, 16 respondents (84.21\%) reported that it "Definitely Did Not Influence" their decision. Three individuals (15.79\%) stated that it had had "Very Little Influence" on them 
leaving. No respondents indicated that it either "Somewhat," "Greatly," or "Definitely Did Influence" them to leave the Extension Service (see Table 11).

The questionnaire asked if insufficient pay was a factor when leaving the Extension Service. Ten individuals (52.63\%) stated that it "Definitely Did Not Influence" their departure and two (10.53\%) noted that it had "Very Little Influence." Four individuals (21.05\%) reported that it "Somewhat Influenced" their decision, two individuals (10.53\%) noted that it "Greatly Influenced," and one individual (5.26\%) reported that it "Definitely Did Influence" their decisions to leave the Extension Service (see Table 11).

When asked if the abilities of the agent did not match the requirement of the job was a factor in their decision to leave, 17 respondents (89.47\%) stated that it "Definitely Did Not Influence" their decisions to leave. No individual stated that it had "Very Little Influence." One respondent (5.26\%) indicated it had "Somewhat Influenced" their decisions to leave. No respondents said that the fact their abilities did not match the requirements of the job "Greatly Influenced" in their departure. One respondent (5.26\%) reported that it "Definitely Did Influence" them to leave the Extension Service (see Table 11).

When asked if a lack of recognition for a job well done was a factor that influenced respondents to leave, 12 individuals (63.16\%) answered that it "Definitely Did Not Influence" their decision. Two respondents (10.53\%) answered that it had "Very Little Influence." Four individuals (21.05\%) noted that lack of recognition "Somewhat Influenced" their decision. No individuals reported that it had "Greatly Influenced" their 
decision; while one individual (5.26\%) reported lack of recognition "Definitely Did Influence" them to leave the Extension Service (see Table 11).

The participants were asked if having an insufficient benefits package was an influencing factor when leaving. Fifteen respondents (78.95\%) stated that it "Definitely Did Not Influence" their departure. Four individuals (21.05\%) reported that it had "Very Little Influence.” There were no responses for "Somewhat Influenced," "Greatly Influenced," or "Definitely Did Influence" (see Table 11).

When asked if the lack of job security had influenced the agents' decision to leave, 15 respondents (79.95\%) indicated that it "Definitely Did Not Influence" their departure from the Extension Service. Two individuals (10.53\%) reported that it had "Very Little Influence" on their outcome. One participant (5.26\%) reported that lack of job security had "Somewhat Influenced" their leaving the Extension Service. No individuals responded with "Greatly Influenced," while one individual (5.26\%) reported that it "Definitely Did Influence" their decision (see Table 11).

The agents were asked to respond whether the lack of opportunities for in-service training was a factor in their decision to leave. Fifteen respondents (79.95\%) indicated that it "Definitely Did Not Influence" their departure from the Extension Service. Two individuals (10.53\%) reported that it had "Very Little Influence" on their outcome. No participant noted that it had "Somewhat Influenced" their leaving the Extension Service. Two individuals (10.53\%) reported that lack of in-service training "Greatly Influenced" influenced them to leave the Extension Service. No individuals responded that it "Definitely Did Influence" their decision (see Table 11). 
The participants were asked if having an inadequate office budget was a factor when leaving the Extension Service. Eleven individuals (57.89\%) answered that it "Definitely Did Not Influence" their decision. Four respondents (21.05\%) answered that it had "Very Little Influence." Two individuals (10.53\%) noted that inadequate office budget had "Somewhat Influenced" their decision. Two individuals (10.53\%) reported that it "Greatly Influenced," while one respondent (5.26\%) reported it "Definitely Did Influence" their decision to leave (see Table 11).

When asked if conflicts with their program unit director was a contributing factor for resignation, 14 individuals (73.38\%) responded that it "Definitely Did Not Influence" their decision. Two individuals (10.53\%) noted that it had "Very Little Influence" on their departure. No respondents responded "Somewhat Influenced." One respondent (5.26\%) reported that conflicts with their program unit director had "Greatly Influenced" their leaving, while two participants (10.53\%) noted that it "Definitely Did Influence" their decision to leave the organization (see Table 11).

The questionnaire asked if lack of feedback regarding their performance was a factor in their decision to leave the organization. Fourteen individuals (73.68\%) answered that it "Definitely Did Not Influence" their decision. One respondent (5.26\%) answered that it had "Very Little Influence." Two individuals (10.53\%) noted that lack of performance feedback "Somewhat Influenced" their decision, while two individuals (11.11\%) reported that it "Greatly Influenced" their decision to leave. No respondents indicated that it "Definitely Did Influence" their resignation (see Table 11).

When asked if the lack of support from on-campus faculty and staff influenced their decision to leave, 12 participants (63.16\%) reported it "Definitely Did Not 
Influence." Four respondents (21.05\%) responded that it had "Very Little Influence" on their leaving the Extension Service. "Somewhat Influenced," "Greatly Influenced," and "Definitely Did Influence" each had one (5.26\%) respondent indicate that it was a factor in them (see Table 11).

The questionnaire asked if the agents not being adequately prepared for the promotion and tenure process was a factor when deciding to leave. Twelve individuals (63.16\%) indicated that it "Definitely Did Not Influence" their position. Three individuals (15.79\%) reported that it had "Very Little Influence" on them leaving. One participant (5.26\%) indicated that it had "Somewhat Influenced" their decision. There were two respondents $(10.53 \%)$ who reported that not being prepared for the promotion and tenure process had "Greatly Influenced" their departure, while one individual (5.26\%) indicated that it "Definitely Did Influence" their departure (see Table 11).

When asked if the changing of administrative policies were a factor, fourteen individuals (73.68\%) indicated that it "Definitely Did Not Influence" their decision to leave. Five respondents (26.32\%) reported that it had "Very Little Influence" on their resignation. There were no responses in either "Somewhat," "Greatly," or "Definitely Did Influence" categories (see Table 11).

The questionnaire asked participants if they had left due to conflicts with their coworkers. Eighteen respondents (94.74\%) stated that factor "Definitely Did Not Influence" their decision to leave the Extension Service. There were no responses in the categories of "Very Little Influence," "Somewhat Influenced," or "Greatly Influenced." One individual (5.26\%) did report that it "Definitely Did Influence" their resignation (see Table 11). 
The participants were asked if the lack of time for professional development led to their leaving their position. Sixteen respondents (84.21\%) indicated that it "Definitely Did Not Influence" their decision. Two individuals (10.53\%) stated that it had "Very Little Influence" on their resignation. One individual (5.26\%) reported that it "Greatly Influenced" their decision. There were no respondents who reported "Somewhat Influenced" or "Definitely Did Influence" (see Table 11).

When asked if participants left due to insufficient funding for programs, 12 (63.16\%) reported that it "Definitely Did Not Influence" them leaving. Three individuals $(15.79 \%)$ indicated that it had "Very Little Influence," while three individuals (15.79\%) reported it had "Somewhat Influenced" their departure. There were no respondents who indicated it had "Greatly Influenced" them, while one respondent (5.26\%) reported that insufficient funding "Definitely Did Influence" their decision to leave (see Table 11).

When asked if respondents left due to the promotion and tenure process not being fair and just, one (5.6\%) respondent did not answer. Eleven individuals (61.11\%) responded that it "Definitely Did Not Influence" their decision. Two respondents (11.11\%) indicated that it had "Very Little Influence." One individual (5.56\%) noted that the fairness of the promotion and tenure process "Somewhat Influenced" their decision to leave, while two individuals (11.11\%) indicated that it "Greatly Influenced," them and two (11.11\%) respondents reported it "Definitely Did Influence." There were 18 respondents to this question (see Table 11). 
Table 11

Organizational Factors that Influenced the Decision to Leave Extension

\begin{tabular}{|c|c|c|c|c|c|c|c|c|c|c|}
\hline & \multicolumn{2}{|c|}{$\begin{array}{l}\text { Definitely Did Not } \\
\text { Influence }\end{array}$} & \multicolumn{2}{|c|}{$\begin{array}{l}\text { Very Little } \\
\text { Influence }\end{array}$} & \multicolumn{2}{|c|}{$\begin{array}{l}\text { Somewhat } \\
\text { Influenced }\end{array}$} & \multicolumn{2}{|c|}{$\begin{array}{c}\text { Greatly } \\
\text { Influenced }\end{array}$} & \multicolumn{2}{|c|}{$\begin{array}{l}\text { Definitely Did } \\
\text { Influence }\end{array}$} \\
\hline & $\mathrm{N}$ & $\%$ & $\mathrm{~N}$ & $\%$ & $\mathrm{~N}$ & $\%$ & $\mathrm{~N}$ & $\%$ & $\mathrm{~N}$ & $\%$ \\
\hline $\begin{array}{l}\text { Little Opportunity for } \\
\text { Advancement }\end{array}$ & 12 & 63.16 & 3 & 15.79 & 3 & 15.79 & 1 & 5.26 & 0 & 0.00 \\
\hline $\begin{array}{l}\text { Amount of Work } \\
\text { Expected }\end{array}$ & 8 & 42.11 & 3 & 15.79 & 3 & 15.79 & 1 & 5.26 & 4 & 21.05 \\
\hline Repetitive Work & 17 & 89.47 & 1 & 5.26 & 0 & 0.00 & 0 & 0.00 & 1 & 5.26 \\
\hline Inadequate Office Space & 13 & 68.42 & 3 & 15.79 & 2 & 10.53 & 1 & 5.26 & 0 & 0.00 \\
\hline $\begin{array}{l}\text { Insufficient Number of } \\
\text { Support Staff }\end{array}$ & 12 & 63.16 & 1 & 5.26 & 2 & 10.53 & 2 & 10.53 & 2 & 10.53 \\
\hline $\begin{array}{l}\text { Lack of Up-To-Date } \\
\text { Equipment }\end{array}$ & 16 & 84.21 & 3 & 15.79 & 0 & 0.00 & 0 & 0.00 & 0 & 0.00 \\
\hline Insufficient Pay & 10 & 52.63 & 2 & 10.53 & 4 & 21.05 & 2 & 10.53 & 1 & 5.26 \\
\hline $\begin{array}{l}\text { Lack of Recognition for } \\
\text { a Job Well Done }\end{array}$ & 12 & 63.16 & 2 & 10.53 & 4 & 21.05 & 0 & 0.00 & 1 & 5.26 \\
\hline
\end{tabular}


Table 11 (continued)

Organizational Factors that Influenced the Decision to Leave Extension

\begin{tabular}{|c|c|c|c|c|c|c|c|c|c|c|}
\hline & \multicolumn{2}{|c|}{$\begin{array}{l}\text { Definitely Did Not } \\
\text { Influence }\end{array}$} & \multicolumn{2}{|c|}{$\begin{array}{l}\text { Very Little } \\
\text { Influence }\end{array}$} & \multicolumn{2}{|c|}{$\begin{array}{l}\text { Somewhat } \\
\text { Influenced }\end{array}$} & \multicolumn{2}{|c|}{$\begin{array}{c}\text { Greatly } \\
\text { Influenced }\end{array}$} & \multicolumn{2}{|c|}{$\begin{array}{l}\text { Definitely Did } \\
\text { Influence }\end{array}$} \\
\hline & $\mathrm{N}$ & $\%$ & $\mathrm{~N}$ & $\%$ & $\mathrm{~N}$ & $\%$ & $\mathrm{~N}$ & $\%$ & $\mathrm{~N}$ & $\%$ \\
\hline \multicolumn{11}{|l|}{ Insufficient Benefits } \\
\hline Package & 15 & 78.95 & 4 & 21.05 & 0 & 0.00 & 0 & 0.00 & 0 & 0.00 \\
\hline Lack of Job Security & 15 & 78.95 & 2 & 10.53 & 1 & 5.26 & 0 & 0.00 & 1 & 5.26 \\
\hline $\begin{array}{l}\text { Lack of Opportunities } \\
\text { for In-Service Training }\end{array}$ & 15 & 78.95 & 2 & 10.53 & 0 & 0.00 & 2 & 10.53 & 0 & 0.00 \\
\hline \multicolumn{11}{|l|}{ Inadequate Office } \\
\hline Budget & 11 & 57.89 & 4 & 21.05 & 2 & 10.53 & 1 & 5.26 & 1 & 5.26 \\
\hline \multicolumn{11}{|l|}{ Conflicts with Program } \\
\hline Unit Director & 14 & 73.68 & 2 & 10.53 & 0 & 0.00 & 1 & 5.26 & 2 & 10.53 \\
\hline \multicolumn{11}{|l|}{ Lack of Feedback } \\
\hline Performance & 14 & 73.68 & 1 & 5.26 & 2 & 10.53 & 2 & 10.53 & 0 & 0.00 \\
\hline
\end{tabular}


Table 11 (continued)

Organizational Factors that Influenced the Decision to Leave Extension

\begin{tabular}{|c|c|c|c|c|c|c|c|c|c|c|}
\hline & \multicolumn{2}{|c|}{$\begin{array}{l}\text { Definitely Did Not } \\
\text { Influence }\end{array}$} & \multicolumn{2}{|c|}{$\begin{array}{l}\text { Very Little } \\
\text { Influence }\end{array}$} & \multicolumn{2}{|c|}{$\begin{array}{l}\text { Somewhat } \\
\text { Influenced }\end{array}$} & \multicolumn{2}{|c|}{$\begin{array}{c}\text { Greatly } \\
\text { Influenced }\end{array}$} & \multicolumn{2}{|c|}{$\begin{array}{l}\text { Definitely Did } \\
\text { Influence }\end{array}$} \\
\hline & $\mathrm{N}$ & $\%$ & $\mathrm{~N}$ & $\%$ & $\mathrm{~N}$ & $\%$ & $\mathrm{~N}$ & $\%$ & $\mathrm{~N}$ & $\%$ \\
\hline $\begin{array}{l}\text { Lack of Support from } \\
\text { On-Campus Faculty and } \\
\text { Staff }\end{array}$ & 12 & 63.16 & 4 & 21.05 & 1 & 5.26 & 1 & 5.26 & 1 & 5.26 \\
\hline $\begin{array}{l}\text { Not Being Adequately } \\
\text { Prepared for the } \\
\text { Promotion and Tenure } \\
\text { Process }\end{array}$ & 12 & 63.16 & 3 & 15.79 & 1 & 5.26 & 2 & 10.53 & 1 & 5.26 \\
\hline $\begin{array}{l}\text { Changing } \\
\text { Administrative Policies }\end{array}$ & 14 & 73.68 & 5 & 26.32 & 0 & 0.00 & 0 & 0.00 & 0 & 0.00 \\
\hline $\begin{array}{l}\text { Conflicts with My Co- } \\
\text { Workers }\end{array}$ & 18 & 94.74 & 0 & 0.00 & 0 & 0.00 & 0 & 0.00 & 1 & 5.26 \\
\hline $\begin{array}{l}\text { Lack of Time for } \\
\text { Professional } \\
\text { Development }\end{array}$ & 16 & 84.21 & 2 & 10.53 & 0 & 0.00 & 1 & 5.26 & 0 & 0.00 \\
\hline
\end{tabular}


Table 11 (continued)

Organizational Factors that Influenced the Decision to Leave Extension

\begin{tabular}{|c|c|c|c|c|c|c|c|c|c|c|}
\hline & \multicolumn{2}{|c|}{$\begin{array}{l}\text { Definitely Did Not } \\
\text { Influence }\end{array}$} & \multicolumn{2}{|c|}{$\begin{array}{l}\text { Very Little } \\
\text { Influence }\end{array}$} & \multicolumn{2}{|c|}{$\begin{array}{l}\text { Somewhat } \\
\text { Influenced }\end{array}$} & \multicolumn{2}{|c|}{$\begin{array}{c}\text { Greatly } \\
\text { Influenced }\end{array}$} & \multicolumn{2}{|c|}{$\begin{array}{l}\text { Definitely Did } \\
\text { Influence }\end{array}$} \\
\hline & $\mathrm{N}$ & $\%$ & $\mathrm{~N}$ & $\%$ & $\mathrm{~N}$ & $\%$ & $\mathrm{~N}$ & $\%$ & $\mathrm{~N}$ & $\%$ \\
\hline $\begin{array}{l}\text { Insufficient Funding for } \\
\text { Programs }\end{array}$ & 12 & 63.16 & 3 & 15.79 & 3 & 15.79 & 0 & 0.00 & 1 & 5.26 \\
\hline $\begin{array}{l}\text { Promotion and Tenure } \\
\text { Process Not Being Fair } \\
\text { and Equitable }\end{array}$ & 11 & 61.11 & 2 & 11.11 & 1 & 5.56 & 2 & 11.11 & 2 & 11.11 \\
\hline
\end{tabular}


The 21 items were combined into an "organizational" construct. The 21 items were averaged. For organizational factors, the researcher found that for the overall construct, females had a mean of 1.60 with a standard deviation of .61, and males had a mean of 1.65 with a standard deviation of .91 .

\section{Job Related Factors Findings}

Respondents were asked to identify key "Job Related Factors" that may have influenced them to leave. There were 19 responses per question unless otherwise stated.

When asked if agents left the Extension Service due to their work not being interesting, 18 respondents (94.74\%) indicated that it "Definitely Did Not" have an influence on their decision. One individual indicated that it had "Greatly Influenced" their decision to leave their position. There were no respondents who reported "Very Little Influence," “Somewhat Influenced," or "Definitely Did Influence" (see Table 12).

A question was asked regarding if their departure was caused by their work not being challenging. All 19 of the respondents $(100.00 \%)$ reported that it "Definitely Did Not Influence" their decisions to leave (see Table 12).

When asked if the agent left due to there not being opportunities to be creative, 17 respondents (89.47\%) reported that it "Definitely Did Not Influence" their decision to leave. One individual (5.26\%) indicated that it "Somewhat Influenced" the agent to leave. One individual (5.26\%) noted that lack of opportunities to be creative had "Greatly Influenced" their departure from the Extension Service. There were no respondents who indicated that it had "Very Little Influence" or that it "Definitely Did Influence" their decision (see Table 12). 
The agents were asked to indicate if they had left due to being over qualified for their position. Sixteen individuals (84.21\%) indicated that it "Definitely Did Not Influence" their decision, while one individual (5.26\%) reported that it had "Very Little Influence" on their departure. Two individuals indicating that it had "Somewhat Influenced" their decision. There were no individuals who responded that it had either "Greatly Influenced" or "Definitely Did Influence" their decision to leave (see Table 12).

When respondents were asked if they had too much supervisor oversight or direction, 16 individuals (84.21\%) stated that it "Definitely Did Not Influence" their decision. Two individuals (10.53\%) indicated that it had "Very Little Influence" on their departure, with one individual reporting that it had "Somewhat Influenced" their decision to leave. There were no individuals who responded that it had either "Greatly Influenced" or "Definitely Did Influence" their decision (see Table 12).

When asked to indicate if they had left due to not being involved with the decision making process, 16 individuals (84.21\%) indicated that it "Definitely Did Not Influence" their decision. One individual (5.26\%) reported that it had "Very Little Influence" on their departure, while two individuals indicated that it had "Somewhat Influenced" their decision. There were no individuals who responded that it had either "Greatly Influenced" or "Definitely Did Influence" their decision to leave (see Table 12).

The participants were asked if they left due to being overall dissatisfied with their work. Seventeen respondents (89.47\%) indicated that it "Definitely Did Not Influence" their decisions to leave. One respondent (5.26\%) reported that it had "Very Little Influence" on their decision. No respondents selected that it had either "Somewhat" or 
"Greatly Influenced" their reason for leaving, while one individual (5.26\%) reported that it "Definitely Did Influence" their departure (see Table 12).

When former agents were asked if having other priorities in their life impacted their decision to leave, six individuals (31.58\%) noted that it "Definitely Did Not Influence" their reasons to leave. None of the respondents stated that it had "Very Little Influence." Four individuals (21.05\%) indicated that it "Somewhat Influenced" their decision, while three individuals (15.79\%) noted that it had "Greatly Influenced" their departure, and the remaining six (31.58\%) reported that it had" Definitely Influenced" their decision to leave (see Table 12).

When asked if agents left the Extension Service due to their work lacking selfdirected freedom, 18 respondents (94.74\%) indicated that it "Definitely Did Not" have influence on their decision while one individual indicated that it had "Very Little Influence" on their decision to leave their position. There were no respondents who chose "Somewhat Influenced," "Greatly Influenced," or "Definitely Did Influence" (see Table 12).

When asked to indicate if they had left due to not having clear job responsibilities, 13 individuals (68.42\%) indicated that it "Definitely Did Not Influence" their decision. Five individuals (26.32\%) reported that it had "Very Little Influence" on their departure, while one individual (5.26\%) selected that it had "Somewhat Influenced" their decision. There were no individuals who responded that it had either "Greatly Influenced" or "Definitely Did Influence" the decision to leave (see Table 12).

When asked if excessive nights, weekends, or overnight commitments were factors, eight respondents (42.11\%) stated that it "Definitely Did Not Influence" them to 
leave. Two individuals (10.53\%) said it had "Very Little Influence." One (5.26\%) respondent reported that it "Somewhat Influenced," their decision while two respondents $(10.53 \%)$ indicated that it "Greatly Influenced," them and six (31.58\%) said that it "Definitely Did Influence" their decisions to leave (see Table 12).

When asked if organizational and personal values that were conflicting contributed as a factor, 14 respondents (73.68\%) stated that it "Definitely Did Not Influence" them to leave. One individual (5.26\%) said it had "Very Little Influence." One $(5.26 \%)$ reported that it "Somewhat Influenced, " while two respondents (10.53\%) indicated that it "Greatly Influenced," and one respondent (5.26\%) said that it "Definitely Did Influence" their decision to leave (see Table 12).

The participants were asked if no matter how much they did, it was never enough was a factor in their leaving Extension. Eleven respondents (57.89\%) stated that it "Definitely Did Not Influence" them to leave. One individual (5.26\%) said it had "Very Little Influence." Two respondents (10.53\%) indicated that it "Somewhat Influenced," their decision, while four respondents (21.05\%) reported that it "Greatly Influenced," and one respondent (5.26\%) said that it "Definitely Did Influence" their decisions to leave (see Table 12).

When asked if being dissatisfied with the distance to in-service training opportunities was a factor for leaving, 12 individuals (63.16\%) reported it "Definitely Did Not" have an influence. Three individuals (15.79\%) indicated that it had "Very Little Influence," and one (5.26\%) reported that they were "Somewhat Influenced" by the dissatisfaction with distance to in-service training. Two individuals (10.53\%) reporting 
that it "Greatly Influenced" their decision, while one respondent (5.26\%) indicated that it "Definitely Did Influence" their departure (see Table 12).

When asked if not having enough oversight from their supervisor was a contributing factor 13 individuals (68.42\%) reported it "Definitely Did Not" have an influence. Two individuals (10.53\%) indicated that it had "Very Little Influence" and two $(10.53 \%)$ responded that they were "Somewhat Influenced" by not having enough oversight from their supervisor. No individuals reported that it "Greatly Influenced" their decision, while one respondent (5.26\%) indicated that it "Definitely Did Influence" their voluntary turnover (see Table 12).

When polled to see if the nature of the job was a factor, 16 individuals $(84.21 \%)$ reported that it "Definitely Did Not Influence" their decision to leave. No individuals chose that it had "Very Little Influence." "Somewhat Influenced," "Greatly Influenced," and "Definitely Did Influence" were noted by one (5.26\%) respondent each (see Table 12.)

The 17 items were combined into a "job related" construct. The 17 items were averaged. For job related factors, the researcher found that for the overall construct, females had a mean of 1.58 with a standard deviation of .45 , and males had a mean of 1.59 with a standard deviation of .88 . 
Table 12

Job Related Factors Influencing Turnover

\begin{tabular}{|c|c|c|c|c|c|c|c|c|c|c|}
\hline & \multicolumn{2}{|c|}{$\begin{array}{l}\text { Definitely Did Not } \\
\text { Influence }\end{array}$} & \multicolumn{2}{|c|}{$\begin{array}{l}\text { Very Little } \\
\text { Influence }\end{array}$} & \multicolumn{2}{|c|}{$\begin{array}{l}\text { Somewhat } \\
\text { Influenced }\end{array}$} & \multicolumn{2}{|c|}{$\begin{array}{c}\text { Greatly } \\
\text { Influenced }\end{array}$} & \multicolumn{2}{|c|}{$\begin{array}{l}\text { Definitely Did } \\
\text { Influence }\end{array}$} \\
\hline & $\mathrm{N}$ & $\%$ & $\mathrm{~N}$ & $\%$ & $\mathrm{~N}$ & $\%$ & $\mathrm{~N}$ & $\%$ & $\mathrm{~N}$ & $\%$ \\
\hline $\begin{array}{l}\text { My Work Was Not } \\
\text { Interesting }\end{array}$ & 18 & 94.74 & 0 & 0.00 & 0 & 0.00 & 1 & 5.26 & 0 & 0.00 \\
\hline $\begin{array}{l}\text { My Work Was Not } \\
\text { Challenging }\end{array}$ & 19 & 100.00 & 0 & 0.00 & 0 & 0.00 & 0 & 0.00 & 0 & 0.00 \\
\hline $\begin{array}{l}\text { Did Not Have } \\
\text { Opportunities to Be } \\
\text { Creative }\end{array}$ & 17 & 89.47 & 0 & 0.00 & 1 & 5.26 & 1 & 5.26 & 0 & 0.00 \\
\hline $\begin{array}{l}\text { Over Qualified for My } \\
\text { Position }\end{array}$ & 16 & 84.21 & 1 & 5.26 & 2 & 10.53 & 0 & 0.00 & 0 & 0.00 \\
\hline $\begin{array}{l}\text { Too Much Supervisor } \\
\text { Oversight or Direction }\end{array}$ & 16 & 84.21 & 2 & 10.53 & 1 & 5.26 & 0 & 0.00 & 0 & 0.00 \\
\hline $\begin{array}{l}\text { Not Involved in the } \\
\text { Decision Making } \\
\text { Process }\end{array}$ & 16 & 84.21 & 1 & 5.26 & 2 & 10.53 & 0 & 0.00 & 0 & 0.00 \\
\hline
\end{tabular}


Table 12 (continued)

Job Related Factors Influencing Turnover

\begin{tabular}{|c|c|c|c|c|c|c|c|c|c|c|}
\hline & \multicolumn{2}{|c|}{$\begin{array}{l}\text { Definitely Did Not } \\
\text { Influence }\end{array}$} & \multicolumn{2}{|c|}{$\begin{array}{l}\text { Very Little } \\
\text { Influence }\end{array}$} & \multicolumn{2}{|c|}{$\begin{array}{l}\text { Somewhat } \\
\text { Influenced }\end{array}$} & \multicolumn{2}{|c|}{$\begin{array}{c}\text { Greatly } \\
\text { Influenced }\end{array}$} & \multicolumn{2}{|c|}{$\begin{array}{l}\text { Definitely Did } \\
\text { Influence }\end{array}$} \\
\hline & $\mathrm{N}$ & $\%$ & $\mathrm{~N}$ & $\%$ & $\mathrm{~N}$ & $\%$ & $\mathrm{~N}$ & $\%$ & $\mathrm{~N}$ & $\%$ \\
\hline $\begin{array}{l}\text { Overall Dissatisfied } \\
\text { with My Work }\end{array}$ & 17 & 89.47 & 1 & 5.26 & 0 & 0.00 & 0 & 0.00 & 1 & 5.26 \\
\hline $\begin{array}{l}\text { Other Priorities in My } \\
\text { Life }\end{array}$ & 6 & 31.58 & 0 & 0.00 & 4 & 21.05 & 3 & 15.79 & 6 & 31.58 \\
\hline $\begin{array}{l}\text { My Abilities Did Not } \\
\text { Match the } \\
\text { Requirements of the } \\
\text { Job }\end{array}$ & 17 & 89.47 & 0 & 0.00 & 1 & 5.26 & 0 & 0.00 & 1 & 5.26 \\
\hline $\begin{array}{l}\text { My Work Lacked Self- } \\
\text { Directing Freedom }\end{array}$ & 18 & 94.74 & 1 & 5.26 & 0 & 0.00 & 0 & 0.00 & 0 & 0.00 \\
\hline $\begin{array}{l}\text { Unclear Job } \\
\text { Responsibilities }\end{array}$ & 13 & 68.42 & 5 & 26.32 & 1 & 5.26 & 0 & 0.00 & 0 & 0.00 \\
\hline $\begin{array}{l}\text { Excessive Night, } \\
\text { Weekend or Overnight } \\
\text { Commitments }\end{array}$ & 8 & 42.11 & 2 & 10.53 & 1 & 5.26 & 2 & 10.53 & 6 & 31.58 \\
\hline
\end{tabular}


Table 12 (continued)

Job Related Factors Influencing Turnover

\begin{tabular}{|c|c|c|c|c|c|c|c|c|c|c|}
\hline & \multicolumn{2}{|c|}{$\begin{array}{l}\text { Definitely Did Not } \\
\text { Influence }\end{array}$} & \multicolumn{2}{|c|}{$\begin{array}{l}\text { Very Little } \\
\text { Influence }\end{array}$} & \multicolumn{2}{|c|}{$\begin{array}{l}\text { Somewhat } \\
\text { Influenced }\end{array}$} & \multicolumn{2}{|c|}{$\begin{array}{c}\text { Greatly } \\
\text { Influenced }\end{array}$} & \multicolumn{2}{|c|}{$\begin{array}{l}\text { Definitely Did } \\
\text { Influence }\end{array}$} \\
\hline & $\mathrm{N}$ & $\%$ & $\mathrm{~N}$ & $\%$ & $\mathrm{~N}$ & $\%$ & $\mathrm{~N}$ & $\%$ & $\mathrm{~N}$ & $\%$ \\
\hline $\begin{array}{l}\text { Organization and } \\
\text { Personal Values Were } \\
\text { in Conflict }\end{array}$ & 14 & 73.68 & 1 & 5.26 & 1 & 5.26 & 2 & 10.53 & 1 & 5.26 \\
\hline $\begin{array}{l}\text { No Matter How Much } \\
\text { I Did, It Was Never }\end{array}$ & & & & & & & & & & \\
\hline Enough & 11 & 57.89 & 1 & 5.26 & 2 & 10.53 & 4 & 21.05 & 1 & 5.26 \\
\hline $\begin{array}{l}\text { Dissatisfied with the } \\
\text { Distance to In-Service } \\
\text { Training Opportunities }\end{array}$ & 12 & 63.16 & 3 & 15.79 & 1 & 5.26 & 2 & 10.53 & 1 & 5.26 \\
\hline $\begin{array}{l}\text { Not Having Enough } \\
\text { Oversight from My } \\
\text { Supervisor }\end{array}$ & 13 & 68.42 & 2 & 10.53 & 2 & 10.53 & 0 & 0.00 & 2 & 10.53 \\
\hline Nature of the Job & 16 & 84.21 & 0 & 0.00 & 1 & 5.26 & 1 & 5.26 & 1 & 5.26 \\
\hline
\end{tabular}




\section{Personal Factors Findings}

The participants were then asked to indicate the level to which "Personal Factors" that may have influenced their decision to leave the Extension Service. There were 19 respondents per question, unless otherwise stated.

When asked if inadequate educational opportunities were a factor when considering leaving Extension, 17 respondents (89.47\%) reported that it "Definitely Did Not Influence." One individual (5.26\%) responded that it had "Very Little Influence," While one other individual stated that it had "Somewhat Influenced" their decision to leave the organization. There were no respondents who selected "Greatly Influenced," or “Definitely Did Influence” (see Table 13).

When asked if of other family obligations had influenced their decision to leave. Seven (36.82\%) participants reported that it "Definitely Did Not Influence" their decision to leave. No respondents stated that it had "Very Little Influence." Three individuals $(15.79 \%)$ indicated that it had "Somewhat Influence" their decision, while three $(15.79 \%)$ respondents reported that it "Greatly Influenced" their decision. There were six respondents (31.58\%) who responded that it "Definitely Did Influence" their resignation (see Table 13).

The participants were asked if they left due to another person's career move. Seventeen respondents (89.47\%) selected that it "Definitely Did Not Influence" their decisions to leave. One respondent (5.26\%) reported that it had "Very Little Influence" on their decision. One individual (5.26\%) indicated that it "Greatly Influenced" their departure. No respondents selected that it had either "Somewhat" or "Definitely Did Influence" their reason for leaving (see Table 13). 
The respondents were asked if they left because of inadequate educational opportunities for other members of my family. Seventeen respondents (89.47\%) selected that it "Definitely Did Not Influence" their decisions to leave. One respondent (5.26\%) reported that it had "Very Little Influence" on their decision. One individual (5.26\%) indicated that it "Somewhat Influenced" their departure. No respondents selected that it had either "Greatly" or "Definitely Did Influence" their resignation (see Table 13).

The questionnaire asked if participant's work conflicted with their personal responsibilities. Nine individuals (47.37\%) indicated that it "Definitely Did Not Influence" their decision. One individual (5.26\%) reported that it had "Very Little Influence." Four individuals (21.05\%) responded that it had "Somewhat Influenced" their personal decision. Two respondents (10.53\%) noted that it had "Greatly Influenced" their resignation. Three participants (15.79\%) reported that it "Definitely Did Influence" their decision to leave the Extension Service (see Table 13).

The participants asked if being dissatisfied with their distance from work to family and friends influenced their decision to leave. Twelve individuals (63.16\%) reported that it "Definitely Did Not Influence" their decision. Two individuals (10.53\%) stated that it had "Very Little Influence." Five individuals (26.32\%) indicated that it had "Somewhat Influenced" their personal decision. No respondents reported that it "Greatly Influenced" or "Definitely Did Influence" their decision to leave (see Table 13).

When asked if the agents did not have enough time for developing personal relationship was a factor, 13 individuals (68.42\%) indicated that it "Definitely Did Not Influence" their decision to leave. The response groups "Very Little Influence" and "Somewhat Influenced" had two respondents each (10.53\%). There were no respondents 
who identified with "Greatly Influenced." Two participants (10.53\%) reported that it "Definitely Did Influence" their resignation from the Extension Service (see Table 13).

When asked if respondents left due to receiving another job offer, 11 individuals (57.89\%) answered that it "Definitely Did Not Influence" their decision. Two respondents (10.53\%) answered that it had "Very Little Influence." One individual $(5.26 \%)$ noted that it "Somewhat Influenced" their decision. Three individuals (15.79\%) reported that it "Greatly Influenced," their decision, while two respondents (10.53\%) reported it "Definitely Did Influence" their departure (see Table 13).

When asked if they decided that this kind of work was not for them had influenced the agents' decision to leave, 15 respondents (79.95\%) chose that it "Definitely Did Not Influence" their departure from the Extension Service. Two individuals (10.53\%) chose that it had "Very Little Influence" on their outcome. One participant (5.26\%) reported that it had "Somewhat Influenced" their leaving the Extension Service. No individuals responded that it "Greatly Influenced" their decision. One individual (5.26\%) reported that it "Definitely Did Influence" their decision (see Table 13).

When asked if participants were attracted to more money elsewhere was a contributing factor 14 individuals (73.68\%) had reported it "Definitely Did Not" have an influence. Two individuals (10.53\%) responded that it had "Very Little Influence," and two participants (10.53\%) indicated that they were "Somewhat Influenced" by more money elsewhere. No individuals reported that it "Greatly Influenced" their decision. One respondent (5.26\%) indicated that it "Definitely Did Influence" their voluntary turnover (see Table 13). 
When asked if the participant left because they wanted to continue their education, 17 respondents (89.47\%) stated that it "Definitely Did Not Influence" their decisions to leave. Two individuals (10.53\%) stated that it had "Very Little Influence." There were no respondents who answered that wanting to continue their education had "Somewhat Influenced," "Greatly Influenced," or "Definitely Did Influence" them to leave the Extension Service (see Table 13).

The participants were asked if the desire to spend more time with family influenced their decision to leave the Extension Service. Six individuals (31.58\%) responded that it "Definitely Did Not" have an influence. One individual (5.26\%) reported that it had "Very Little Influence," while four (21.05\%) indicated that they were "Somewhat Influenced" by the desire to spend more time with their family. One individual (5.26\%) responded that it "Greatly Influenced" their decision, while seven respondents (36.84\%) reported that it "Definitely Did Influence" their departure from the Extension Service (see Table 13).

When asked if not having enough time for maintaining personal relationships, eight respondents (42.11\%) indicated that it "Definitely Did Not Influence" their decision. Three individuals (15.79\%) cited that it had "Very Little Influence" when leaving. Three participants (15.79\%) reported that it had "Somewhat Influenced" their resignation. Two (10.53\%) individuals responded that it had "Greatly Influenced" their decision. Three respondents (15.79\%) reported that not having enough time for maintaining personal relationships "Definitely Did Influence" their decision to leave the Extension Service (see Table 13). 
Participants were asked if they left to do more meaningful work. Sixteen participants (84.21\%) responded that it "Definitely Did Not Influence" their decision. Two individuals chose that it had "Very Little Influence," while one person (5.26\%) reported that it "Somewhat Influenced" them. There were no respondents who chose that it had "Greatly" or "Definitely Did Influence" their decision to leave (see Table 13).

The 14 items were combined into a "personal factors" construct. The 14 items were averaged. For personal factors, the researcher found that for the overall construct, females had a mean of 1.85 with a standard deviation of .64, and males had a mean of 1.70 with a standard deviation of .63 . 
Table 13

\section{Non-Job Related Factors}

\begin{tabular}{|c|c|c|c|c|c|c|c|c|c|c|}
\hline & \multicolumn{2}{|c|}{$\begin{array}{l}\text { Definitely Did Not } \\
\text { Influence }\end{array}$} & \multicolumn{2}{|c|}{$\begin{array}{l}\text { Very Little } \\
\text { Influence }\end{array}$} & \multicolumn{2}{|c|}{$\begin{array}{l}\text { Somewhat } \\
\text { Influenced }\end{array}$} & \multicolumn{2}{|c|}{$\begin{array}{c}\text { Greatly } \\
\text { Influenced }\end{array}$} & \multicolumn{2}{|c|}{$\begin{array}{l}\text { Definitely Did } \\
\text { Influence }\end{array}$} \\
\hline & $\mathrm{N}$ & $\%$ & $\mathrm{~N}$ & $\%$ & $\mathrm{~N}$ & $\%$ & $\mathrm{~N}$ & $\%$ & $\mathrm{~N}$ & $\%$ \\
\hline Inadequate & & & & & & & & & & \\
\hline $\begin{array}{l}\text { Educational } \\
\text { Opportunities }\end{array}$ & 17 & 89.47 & 1 & 5.26 & 1 & 5.26 & 0 & 0.00 & 0 & 0.00 \\
\hline Family Obligations & 7 & 36.84 & 0 & 0.00 & 3 & 15.79 & 3 & 15.79 & 6 & 31.58 \\
\hline $\begin{array}{l}\text { Another Person's } \\
\text { Career Move }\end{array}$ & 17 & 89.47 & 1 & 5.26 & 0 & 0.00 & 1 & 5.26 & 0 & 0.00 \\
\hline $\begin{array}{l}\text { Inadequate } \\
\text { Educational } \\
\text { Opportunities for } \\
\text { Other Members of My }\end{array}$ & & & & & & & & & & \\
\hline Family & 17 & 89.47 & 1 & 5.26 & 1 & 5.26 & 0 & 0.00 & 0 & 0.00 \\
\hline $\begin{array}{l}\text { My Work Conflicted } \\
\text { with My Personal }\end{array}$ & & & & & & & & & & \\
\hline Responsibilities & 9 & 47.37 & 1 & 5.26 & 4 & 21.05 & 2 & 10.53 & 3 & 15.79 \\
\hline $\begin{array}{l}\text { Dissatisfied with } \\
\text { Distance from Work to } \\
\text { Family and Friends }\end{array}$ & 12 & 63.16 & 2 & 10.53 & 5 & 26.32 & 0 & 0.00 & 0 & 0.00 \\
\hline
\end{tabular}


Table 13 (continued)

\section{Non-Job Related Factors}

\begin{tabular}{|c|c|c|c|c|c|c|c|c|c|c|}
\hline & \multicolumn{2}{|c|}{$\begin{array}{l}\text { Definitely Did Not } \\
\text { Influence }\end{array}$} & \multicolumn{2}{|c|}{$\begin{array}{l}\text { Very Little } \\
\text { Influence }\end{array}$} & \multicolumn{2}{|c|}{$\begin{array}{l}\text { Somewhat } \\
\text { Influenced }\end{array}$} & \multicolumn{2}{|c|}{$\begin{array}{c}\text { Greatly } \\
\text { Influenced }\end{array}$} & \multicolumn{2}{|c|}{$\begin{array}{l}\text { Definitely Did } \\
\text { Influence }\end{array}$} \\
\hline & $\mathrm{N}$ & $\%$ & $\mathrm{~N}$ & $\%$ & $\mathrm{~N}$ & $\%$ & $\mathrm{~N}$ & $\%$ & $\mathrm{~N}$ & $\%$ \\
\hline $\begin{array}{l}\text { Not Enough Time for } \\
\text { Developing Personal } \\
\text { Relationships }\end{array}$ & 13 & 68.42 & 2 & 10.53 & 2 & 10.53 & 0 & 0.00 & 2 & 10.53 \\
\hline $\begin{array}{l}\text { Received Another Job } \\
\text { Offer }\end{array}$ & 11 & 57.89 & 2 & 10.53 & 1 & 5.26 & 3 & 15.79 & 2 & 10.53 \\
\hline $\begin{array}{l}\text { Decided That This } \\
\text { Kind of Work Was } \\
\text { Not for Me }\end{array}$ & 15 & 78.95 & 2 & 10.53 & 1 & 5.26 & 0 & 0.00 & 1 & 5.26 \\
\hline $\begin{array}{l}\text { Attracted to More } \\
\text { Money Elsewhere }\end{array}$ & 14 & 73.68 & 2 & 10.53 & 2 & 10.53 & 0 & 0.00 & 1 & 5.26 \\
\hline $\begin{array}{l}\text { Wanted to Continue } \\
\text { My Education }\end{array}$ & 17 & 89.47 & 2 & 10.53 & 0 & 0.00 & 0 & 0.00 & 0 & 0.00 \\
\hline $\begin{array}{l}\text { Desire to Spend More } \\
\text { Time with My Family }\end{array}$ & 6 & 31.58 & 1 & 5.26 & 4 & 21.05 & 1 & 5.26 & 7 & 36.84 \\
\hline
\end{tabular}


Table 13 (continued)

Non-Job Related Factors

\begin{tabular}{|c|c|c|c|c|c|c|c|c|c|c|}
\hline & \multicolumn{2}{|c|}{$\begin{array}{l}\text { Definitely Did Not } \\
\text { Influence }\end{array}$} & \multicolumn{2}{|c|}{$\begin{array}{l}\text { Very Little } \\
\text { Influence }\end{array}$} & \multicolumn{2}{|c|}{$\begin{array}{l}\text { Somewhat } \\
\text { Influenced }\end{array}$} & \multicolumn{2}{|c|}{$\begin{array}{c}\text { Greatly } \\
\text { Influenced }\end{array}$} & \multicolumn{2}{|c|}{$\begin{array}{l}\text { Definitely Did } \\
\text { Influence }\end{array}$} \\
\hline & $\mathrm{N}$ & $\%$ & $\mathrm{~N}$ & $\%$ & $\mathrm{~N}$ & $\%$ & $\mathrm{~N}$ & $\%$ & $\mathrm{~N}$ & $\%$ \\
\hline $\begin{array}{l}\text { Not Enough Time for } \\
\text { Maintaining Personal } \\
\text { Relationships }\end{array}$ & 8 & 42.11 & 3 & 15.79 & 3 & 15.79 & 2 & 10.53 & 3 & 15.79 \\
\hline $\begin{array}{l}\text { Do More Meaningful } \\
\text { Work }\end{array}$ & 16 & 84.21 & 2 & 10.53 & 1 & 5.26 & 0 & 0.00 & 0 & 0.00 \\
\hline
\end{tabular}


The participants were asked to respond to an opened ended question regarding the number one reason they left the Extension Service. Their results were analyzed and categorized into groups of primary reasons. One individual $(5.26 \%)$ noted that job security was their number one reason for leaving the Extension Service. Three respondents $(15.79 \%)$ reported family obligation being the primary reason for their departure. Three participants $(15.79 \%)$ responded that stressors of the job were responsible for them leaving the Extension Service. There were seven respondents (36.84\%) who said their primary reason for leaving Extension was retirement. Lack of administrative support, no room for advancement, too much work for not enough pay, and receiving a higher position in Extension each had one respondent (5.26\%). There were a total of 18 responses that were categorized. A full list of respondents' answers can be found in Appendix C (see Table 14).

Table 14

Primary Reasons for Leaving

\begin{tabular}{lcc}
\hline & $\mathrm{N}$ & $\%$ \\
\hline Job Security & 1 & 5.26 \\
Family Obligations & 3 & 15.79 \\
Stress of the Job & 3 & 15.79 \\
Retirement & 7 & 36.84 \\
Lack of Administrative Support & 1 & 5.26 \\
No Room for Advancement & 1 & 5.26 \\
Too Much Work for Not Enough Pay & 1 & 5.26 \\
Another Job in Extension & 1 & 5.26 \\
\hline
\end{tabular}

*Percent is based on 18 responses 
The participants were asked to indicate if there were any factors that if changed would have influenced them to remain in the Extension Service. Seven respondents noted, times that if changed would have influenced them to remain. One individual noted that they would have stayed with the Extension Service if there were a better help system for promotion and tenure. Another former agent noted that if they were not located in a single-agent county, then they would have stayed. One individual noted that if they knew how to get help from a [ ] specialist then they would have stayed. Another respondent noted they needed information on how to utilize the volunteers they had. The primary reason that could have kept one agent in the field would have been for the directors to show more appreciation for the work of the agent. Two respondents wrote that if there were a way to reduce the amount of summer obligations, then they would have stayed an agent. Full responses to this section can be found in Appendix E (see Table 15).

Table 15

What Could Have Kept You from Leaving $(n=19)$

\begin{tabular}{lcc}
\hline & $\mathrm{N}$ & $\%$ \\
\hline P \& T System Help & 1 & 5.26 \\
Not be a Single Agent County & 1 & 5.26 \\
Help from a [ ] Specialist & 1 & 5.26 \\
How to Utilize Volunteers & 1 & 5.26 \\
Felt Appreciated for Work from Directors & 1 & 5.26 \\
Reduce Summer Obligations & 2 & 10.53 \\
No Response & 12 & 63.16 \\
\hline
\end{tabular}




\section{CHAPTER V}

\section{Conclusions/Recommendations/Implications}

\section{Purpose of Study}

The purpose of this study was to determine the key factors that were causing turnover rates in the West Virginia University Extension Service (WVUES) to remain at an elevated level. This information will be useful to the administration and human resource divisions of the WVUES. Outcomes of this study can be used to identify key retention factors, as well as provide information relevant to the recruitment of new individuals.

\section{Objectives}

The objectives of this study were reflected in the following research questions:

1. What job related factors and experiences impacted Extension Agents' decisions to leave the organization?

2. What organizational factors impacted Extension Agents' decisions to leave the organization?

3. What personal factors and experiences influenced Extension Agents' decisions to leave the organization?

4. Describe the characteristics of Extension Agents who voluntarily leave the organization.

5. Determine the most significant factors that influence Extension Agents to leave the WVUES. 


\section{Summary}

The study found that most people leaving the Extension Service were natives of the state. The majority of the individuals who left were women with their age being over 60. Most of the individuals who left worked in the program areas of either 4-H Youth Development or Agriculture and Natural Resources. The study also found that the majority of the individuals did not originally choose to go into the Extension Service and Extension was not their first job. Most of the population identified themselves as being married, with no children living in their household.

Organizational factors which were most frequently reported as impacting their decision to leave Extension were: the amount of work expected and not enough pay. Having other priorities in my life was the most influential job related factor. Other job related factors included: excessive nights and weekends, or overnight commitments, and no matter how much agents did, it was never enough. In regard to personal related factors, a desire to spend more time with their families and friends was a major factor influencing turnover. Other influential personal related factors included: not enough time for maintaining personal relationships and work conflicting with personal responsibilities.

\section{Recommendations}

The following recommendations are based upon the findings of this study:

1. West Virginia University Extension Service administrators need to assess the work load of agents. Consideration should be given to excessive nights and weekends, and overnight commitments since these are noted as the primary reason for turnover among the respondents. 
2. Extension administration should evaluate the recognition of the agents while in office. The feeling of never doing enough was noted as a reason for turnover. More effort should be made by administrators to acknowledge the work being done by agents in their units.

3. Extension administration should assign mentors to new agents, so they have someone to reach out to during the first year at least.

4. Extension should provide in-service training for agents on time management and how to work life balance, since not having enough time for personal relationships, a desire to spend more time with family, and family obligations were all highly noted as reasons for leaving. The ability to achieve a balance between work and social life is key to retention of agents.

\section{Recommendations for Further Study}

1. Further studies need to be conducted on the amount of training agents receive prior to being placed in a county office.

2. Induction and on-boarding protocols need to be examined to determine how agents can be better prepared and supported in the field.

3. This study should be replicated in other states to see how responses compare.

4. A study should be conducted to determine how other state Extension Services are set up and see if the organization influences turnover rates. 


\section{REFERENCES}

Arnold, S. (2007). Career decisions of Florida agricultural extension agents. Published doctoral dissertation. University of Florida, Gainesville, Florida.

Arnold, S. \& Place, N. (2010, February). What influences agents to pursue a career in Extension, Journal of Extension, 48(1) Article 1RIB1. www.joe.org/joe/2010february/rb1.php

Bouckennooghe, D., Raja, U. \& Butt, A. (2013) Combined effects of positive and negative affectivity and job satisfaction on job performance and turnover intentions, Journal of Psychology: Interdisciplinary and Applied, 147(2), 105123.

Carter, B. C. G. (1989.) Factors related to turnover intentions of Louisiana Cooperative Extension Service agents. Published doctoral dissertation. The Louisiana State University, Baton Rouge, Louisiana.

Carter, C. G., Pounder, D. G., Lawrence, F. G., \& Wozniak, P. J. (1989). Factors related to organizational turnover intentions of Louisiana extension service agents. Quality-of-Life Studies in Marketing and Management, 170-181.

Clark, R. (1992). Stress and turnover among Extension directors, Journal of Extension, 30(2) Article 2RIB1 http://www.joe.org/joe/1992summer.rb1.php

Dillman, D. A. (1991). The design and instrumentation of mail surveys, Annual Review of Sociology $17,225-249$

Ensle, K. (2005, June) Burnout: How does Extension balance job and family, Journal of Extension, 43(3) Article 3FEA5. http://www.joe.org/joe/2005june/a5.php 
Fetsch, R., Flashman, R. \& Jeffiers, D. (1984, May). Up tight ain’t right: Easing the pressure on County Agents, Journal of Extension, 22(3) Article 3FEA4 http://www.joe.org/joe/1984may/a4.php

Fetsch, R. \& Kennington, M. (1997, February). Balancing work and family in Cooperative Extension: History, effective programs, and future directions. Journal of Extension, 35(1) Article 1FEA2. http://www.joe.org/joe/1997february/a2.php

Harder, A., Gouldthorpe, J. \& Goodwin, J. (2014, June). Why work for Extension? An examination of job satisfaction and motivation in a statewide employee retention study, Journal or Extension, 52(3) Article 3FEA5. http://www.joe.org/joe/2014june/a5.php

Hom, P. \& Kinicki, A. (2001, October). Toward a greater understanding of how dissatisfaction drives employee turnover. The Academy of Management Journal, 44(5), 975-987 http://www.jstor.org/stable/3069441

Igodan, O. \& Newcomb, L. H. (1986). Are you experiencing burnout? Journal of Extension, 24(1) Article 1FEA1 http://www.joe.org/joe/1986spring/a1.php Johnson, E. (1992). Job satisfaction of Extension faculty employed by the West Virginia University Extension Service. Unpublished Master's thesis, West Virginia University, Morgantown, West Virginia.

Kutilek, M. (2000, June). Learning from those who leave. Journal of Extension, 38(3) Article 3IAW2 http://www.joe.org/joe/2000june/iw2.php 
Lee, T. \& Mowday, R. (1987). Voluntarily leaving an organization: An empirical investigation of Steer and Mowday's Model of Turnover. The Academy of Management Journal, 30(4) 721-743 http://www.jstor.org/stable256157

Manton, L. \& van Es, J.C. (1985). Why do agents resign? Journal of Extension, 23(3) Article 3FEA4. http://www.joe.org/joe/1985fall/a4.php

Mobley, W.H. (1982). Employee turnover: Causes consequences, and control. Reading. MA: Addison Weakley

Mowbray, J. \& Logan, J. (2002). Factors affecting turnover of County Extension Agents in the University of Kentucky Cooperative Extension Service, Published doctoral dissertation. University of Kentucky, Lexington, Kentucky.

Riggs, K. \& Beus, K. (1993). Job satisfaction in Extension. Journal of Extension, 31(2) Article 2FEA5. http://www.joe.org/joe/1993summer/a5.php

Robinson, J.P., Shaver, P.R., \& Wrightsman, L.S. (1991). Criteria for scale selection and evaluation. In J.P., P.R. Shaver, \& L.S. Wrightsman (EDS.). Measures of Personality and Social Psychological Attitudes (pp. 1-16) New York: Academic Press

Rousan, L. (1995). Agent turnover in Ohio State University Extension, Published doctoral dissertation. The Ohio State University, Columbus, Ohio.

Rousan, L. \& Henderson, J. (1996). Agent turnover in Ohio State University Extension, Journal of Agricultural Education, 37(2) 56-62. 
APPENDICES 
APPENDIX A

Cover Letter 
January 5, 2015

Dear Former WVU Extension Service County Agent:

As an agent, you have experienced the impact of employment with the WVU Extension Service. It is important to gain insight into factors which impacted your decision to leave employment with WVU Extension. To reach that goal, your assistance is vital.

My name is Michael Withrow, a graduate student at West Virginia University. I am working with my advisor Dr. Deborah Boone, to conduct a study on factors that have influenced County Extension Agents to leave employment with WVU Extension. This study will attempt to gather information on the identifiable factors that impacted agents to voluntarily leave the West Virginia Extension Service. The results of this study will be used to prepare a thesis to partially fulfill the requirements for a Master of Science degree in Agricultural and Extension Education.

Participation in this double blind research study is completely voluntary and all information you provide will be held as confidential as possible. The researchers do not know your names and the Extension Service will not see returned surveys, surveys will be returned to the researchers, not Extension. The questionnaire should take approximately fifteen minutes to complete. You may skip any question you do not feel comfortable answering and may stop at any point and submit a partially completed survey. You will notice a number at the top left-hand side of the return envelope. This number will only be used to identify non-respondents for follow-up and will be destroyed before the data are analyzed. The results of this survey will be reported in a summary format and individual responses will be not be identifiable. You must be 18 years of age to participate in this study.

The Institutional Review Board (IRB) at West Virginia University has approved this study and the acknowledgement of this research is on file. If you have questions or concerns about completing the survey or participating in the study, please contact me at mwithro5@mix.wvu.edu or my advisor Dr. Deborah Boone at debby.boone@mail.wvu.edu or 304-293-5450.

Place the completed questionnaire in the enclosed postage-paid self-addressed return envelope and drop it in the mail. As an incentive, we will be drawing a name to receive a $\$ 50$ Walmart gift card. If you would like to be included in the drawing, please fill out the slip included in this packet and return it with your survey. Please return your completed survey by Friday, January 16, 2015. Thank you in advance for your participation in this study. We sincerely appreciate your time and assistance.

Sincerely,

Michael Withrow

Graduate Student
Deborah A. Boone, Ph.D. Associate Professor 
APPENDIX B

Follow-up Letter 
January 20, 2015

Dear Former WVU Extension Service County Agent:

Two weeks ago you were sent a questionnaire and we have not yet received a response. Your input is highly valuable as a former County Extension Agent. It is important to gain insight into factors which impacted your decision to leave employment with WVU Extension. To reach that goal, your assistance is vital.

My name is Michael Withrow, a graduate student at West Virginia University. I am working with my advisor Dr. Deborah Boone, to conduct a study on factors that have influenced County Extension Agents to leave employment with WVU Extension. This study will attempt to gather information on the identifiable factors that impacted agents to voluntarily leave the West Virginia Extension Service. The results of this study will be used to prepare a thesis to partially fulfill the requirements for a Master of Science degree in Agricultural and Extension Education.

Participation in this double blind research study is completely voluntary and all information you provide will be held as confidential as possible. The researchers do not know your names and the Extension Service will not see returned surveys, surveys will be returned to the researchers, not Extension. The questionnaire should take approximately fifteen minutes to complete. You may skip any question you do not feel comfortable answering and may stop at any point and submit a partially completed survey. You will notice a number at the top left-hand side of the return envelope. This number will only be used to identify non-respondents for follow-up and will be destroyed before the data are analyzed. The results of this survey will be reported in a summary format and individual responses will be not be identifiable. You must be 18 years of age to participate in this study.

The Institutional Review Board (IRB) at West Virginia University has approved this study and the acknowledgement of this research is on file. If you have questions or concerns about completing the survey or participating in the study, please contact me at mwithro5@mix.wvu.edu or my advisor Dr. Deborah Boone at debby.boone@mail.wvu.edu or 304-293-5450.

Place the completed questionnaire in the enclosed postage-paid self-addressed return envelope and drop it in the mail. As an incentive, we will be drawing a name to receive a $\$ 50$ Walmart gift card. If you would like to be included in the drawing, please fill out the slip included in this packet and return it with your survey. Please return your completed survey by Wednesday, February 4, 2015. Thank you in advance for your participation in this study. We sincerely appreciate your time and assistance.

Sincerely,

Michael Withrow

Graduate Student
Deborah A. Boone, Ph.D. Associate Professor 
APPENDIX C

Comments to Organizational Factors 


\section{Comments to Organizational Factors}

"I loved the organization. I retired after [years] of service. Could have retired years earlier but loved my job"

"I felt my program unit director was overly concerned about not ruffling feathers with the non-Extension parts of the university to the extent of not supporting my work and struggles with those non-Extension units and people."

"Unit directors all treated me horribly. They were very condescending and rude. I couldn't get a response on simple emails without the entire administration being carbon copied on emails. I was not respected as an agent. [Agents] are phenomenal and were excellent mentors and examples."

"Promotion and tenure was a totally cumbersome process taking too much program time and too much budget regarding Extension administration.”

"All my former colleagues were great to work with. Unfortunately I had colleagues in my county that I often felt didn't support me. To make the changes of improvement needed with the county [program] I managed, I needed support from my county peers and the program directors in [city, state]. Additionally the job was not what I expected to be upon interview process and application materials." 
"I wish there were more assistance in the county budgeting and trying to make funding opportunities more available. Our county needed a program assistant or at least a way to increase funding to staff more support."

"Single agent county with zero program support staff, yet county and service expected same service as counties with multiple staff and the work load got to the point that if was affecting my health" 
APPENDIX D

Comments to Job Related Factors 


\section{Comments to Job Related Factors}

"I gave $150 \%$ to the Extension for [years] time to focus on me and my personal life I left an agent position, but found different position in [Extension Service].”

"I feel there is such a great expectation to be perfect in all realms of the service teaching and scholarly works. I do not feel my experience with the faculty file took certain considerations in my mind. I had difficulty finding that niche of "faculty" quality research while I had to maintain my large community club county. I also do not feel they were graded fairly. If our main areas of service are teaching and service and I had good but not that many research projects, why be criticized?"

"Too much seat work and not enough opportunity to work with kids. I felt that the job was more tailored for a [sic] or management specialist. Rather than someone, such as myself, who came from background in education. Paperwork was ridiculous. Also, all I seemed to do was plan/coordinate events and solve selfish and petty things with adult volunteers."

"I retired to do other life changing opportunities." 
APPENDIX E

Comments in Personal Factors 


\section{Comments in Personal Factors}

"I left Extension after [years] of a very satisfactory career to take part on our family farm. The farm needed me and I was ready to step on to the next chapter of my life."

"To be honest I was out of place working with extension. From the moment I started to the day I left I never felt like I belonged. The county I worked for never appreciated the time, effort, and ideas I had, because I was not from WV, the county I worked in, I didn't grow up in 4-H. I felt unwanted and was challenged often with no support from the other agents in my county or university. When it came to camp in particular, the volunteers purposely went against policies/rules created by me and "looked the other way" when campers did. Furthermore, the volunteers at camp thought they were campers and not there to actually perform as camp staff. It seemed camp more about the adult volunteers rather that the kids."

"My family did not like the evening away from home due to meetings, weeks away due to camp, nor the weeks away due to professional development. Along with the stress from dealing with timelines and volunteer issues, it is easy to see why my family did not like my being away so much.”

"Agents spend a lot of evenings, weekends on the job. Actually you are never off the job. People call you in the grocery store or even at church with work questions. It's exhausting." 


\section{APPENDIX F}

Comments on Main Reason for Leaving 


\section{Comments on Main Reason for Leaving}

"Secured another job in [agency]."

"Moved in with boyfriend and to be closer to my father. Also stress of being an agent in a county by myself was killing me."

"I was not present enough at home. My family wanted me to find another position.

Overall stress and requirements were also a factor. Volunteers!"

"The job was not what I it was going to be. I thought I would have the opportunity to work more often/closely with kids. Instead, I spent most of my time sitting at a desk planning, coordinating events and doing too much paperwork. Also, challenging people in county I served in that were against changes, especially if it was a tradition at camp."

"Far too much of my time was consumed with little pay. I now have a job where I work fewer hours and I am paid the same."

"Retirement after a productive extension service career."

"Accepted a teaching position closer to my home."

"Retirement" (5 respondents)

"Administration lack of support. I didn't have room for advancement. I was tired of being treated like a peasant."

"I had a child. Breastfeeding was a priority to maximize health benefits for my child."

"I was hoping to work primarily in my county but quickly realized a large percentage of time was spent in other counties." 
APPENDIX G

Responses to What Could Have Prevented Agents From Leaving? 


\section{Responses to What Could Have Prevented Agents From Leaving?}

"I would have stayed without a doubt if I could have worked. The majority of the time in my county."

"No! I loved every minute of my job!"

"No- Loved everything about Extension."

"I tried to set up a "sitter" next door to the Extension Office, so I could visit for feedings, but that was denied by WVUES. I wasn't willing to pump, but I loved my job at WVUES."

"Yes, if administration would have been appreciative of my contributions. I worked in a complex office with numerous issues. I was there to serve and grow. Unfortunately, I was not appreciated. The county in which I worked pleaded with me to stay. I had more selfrespect than that."

"Not by the Extension Service."

"Fewer summer obligations, particularly county fair increased pay."

"More support from volunteer specialist. More head's up on actual skills/ways to deal with volunteer issues."

"Never have an agent in a county by themselves an expect them to do everything."

"More training in the beginning. Maybe opportunity to shadow more experienced agent for a week prior to starting. More involvement from the program director. More support from colleagues/other agents in the county I worked in. Better communication during interview of what the job actually was." 
APPENDIX H

Additional Comments 


\section{Additional Comments}

"I believe new hires should be made aware of the competitiveness between coworkers/peers in Extension."

"I found the opportunities where I worked to be very stimulating. My co-workers and administrative staff the best of the best and the clientele I served to be very progressive."

"I know my job made a difference. I had wonderful supervisors who cared. I received top notch professional development opportunities and received numerous awards."

"If I could have taken 1 year off or have found an accomidation [sic], I have no doubt that I would still be working for WVUES today."

"Administration needs to learn how to treat others. [Program Unit Director] needs to go. [Director] was the rudest person I encountered. [Director] acted better than everyone else and was not approachable. I would have made extension my career for life had I been supported and treated like a human."

"I loved my job but realized it was time to retire."

"A system should be devised that separated program leadership from supervision and allowed for closer supervision. The promotion and tenure system has greatly improved salaries and status of agents with in the university."

"New agents with no experience in extension need a lot of training, job shadowing, and support. Much more than I received. Don't start a new agent with one preparing them of checking in on them on a regular basis. Also, make it more about the kids and education/preparation for their future. Much less about the volunteers, 4-H tradition and meaningless paperwork. Last, it shouldn't take so much time to complete faculty file. The file made it difficult to do my job because it took so much time to complete."

"I have never experienced a more rewarding career than extension. I feel that it has to take a special person to keep up with all of the demands. As much stress and turmoil I faced while employed as an agent, I wouldn't have traded it for the world. However, I do wish and think that a few of the issues could have been dealt with in a proactive manner."

"I never thought it was fair to call agents university faculty, when far more time was demanded out of them than a WVU on campus faculty member for the same pay. In summers, I often worked 1-2 weeks (or more) of overnight camps, and 14-16 hour days (a)county fair time."

"During the fall/winter I was on numerous overnight and weekend trips. There was no camp time available." 
"I hate that even though my program director thought I was doing a good job, the Extension Service Committee could have me out of a job if they wished."

"I miss Extension, my former co-workers but the demands on time vs. pay were just overwhelming." 
APPENDIX I

Instrument 


\section{Identifying Factors Related to Turnover in West Virginia University Extension Agents}

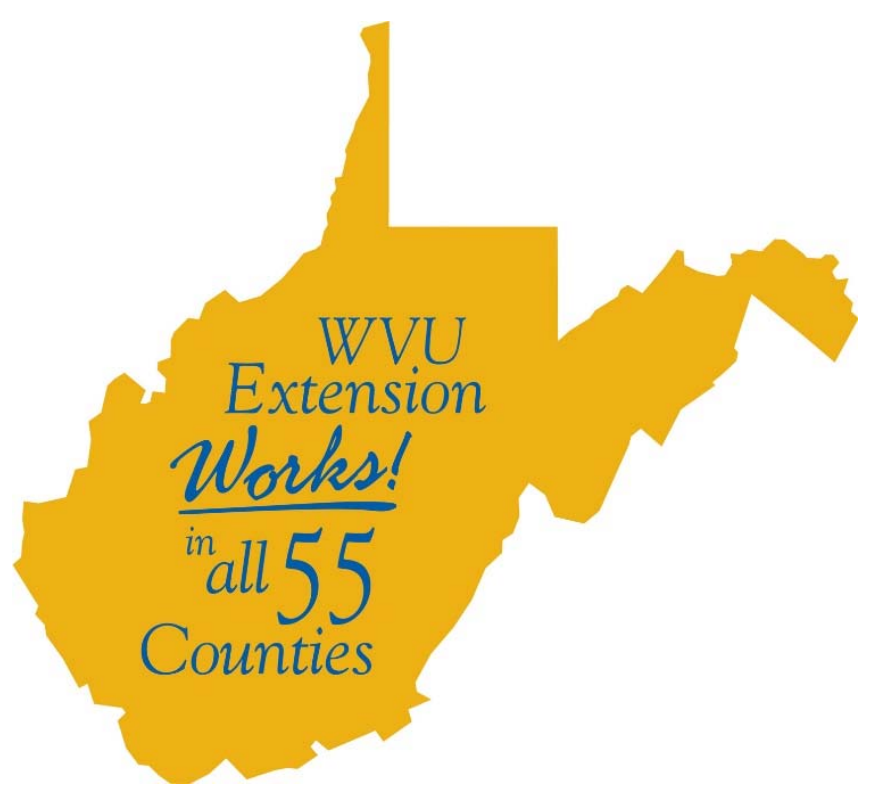

Michael Blaine Withrow

Graduate Student

Agricultural and Extension Education

Davis College of Agriculture, Natural Resource, and Design

West Virginia University

Morgantown, WV 26506 
The following are factors which may have influenced West Virginia University Extension Agents to leave the organization. Please read each statement carefully and mark your responses on the Likert type scale ranging from Definitely Did Not Influence, to Definitely Influenced by circling the corresponding letters.

If the statement Definitely Did Not Influence you leaving, please circle DNI.

If the statement had Very Little Influence on you leaving, please circle VLI.

If the statement had Somewhat of an Influence on you leaving, please circle SI.

If the statement had Greatly Influenced you to leave, please circle GI.

If the statement Definitely Influenced you to leave, please circle DI.

\begin{tabular}{|l|l|c|c|c|c|}
\hline $\begin{array}{l}\text { Example: I } \\
\text { left WVU } \\
\begin{array}{l}\text { Extension } \\
\text { because: }\end{array}\end{array}$ & $\begin{array}{l}\text { Definitely } \\
\text { Did Not } \\
\text { Influence }\end{array}$ & $\begin{array}{l}\text { Very Little } \\
\text { Influence }\end{array}$ & $\begin{array}{l}\text { Somewhat } \\
\text { Influenced }\end{array}$ & $\begin{array}{l}\text { Greatly } \\
\text { Influenced }\end{array}$ & $\begin{array}{l}\text { Definitely } \\
\text { Influenced }\end{array}$ \\
\hline $\begin{array}{l}\text { my position } \\
\text { did not } \\
\text { make a } \\
\text { difference }\end{array}$ & DNI & VLI & SI & GI & DI \\
\hline
\end{tabular}

This respondent has stated their position not making a difference GREATLY

INFLUENCED them to leave the WVU Extension Service. 


\section{Organizational Factors}

\begin{tabular}{|c|c|c|c|c|c|}
\hline I left WVU Extension because of... & 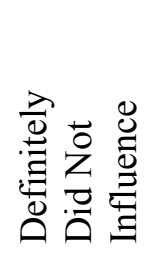 & 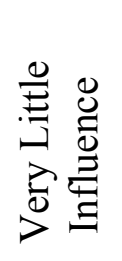 & 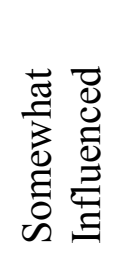 & 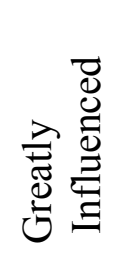 & 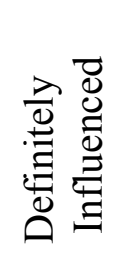 \\
\hline 1. little opportunity for advancement. & DNI & VLI & SI & GI & DI \\
\hline 2. the amount of work expected. & DNI & VLI & SI & GI & DI \\
\hline 3. repetitive work. & DNI & VLI & SI & GI & DI \\
\hline 4. inadequate office space. & DNI & VLI & SI & GI & DI \\
\hline 5. insufficient number of support staff. & DNI & VLI & SI & GI & DI \\
\hline 6. a lack of up-to-date equipment. & DNI & VLI & SI & GI & DI \\
\hline 7. insufficient pay. & DNI & VLI & SI & GI & DI \\
\hline $\begin{array}{l}\text { 8. a lack of recognition for a job well } \\
\text { done. }\end{array}$ & DNI & VLI & SI & GI & DI \\
\hline 9. an insufficient benefits package. & DNI & VLI & SI & GI & DI \\
\hline 10. a lack of job security. & DNI & VLI & SI & GI & DI \\
\hline $\begin{array}{l}\text { 11. lack of opportunities for in-service } \\
\text { training. }\end{array}$ & DNI & VLI & SI & GI & DI \\
\hline 12. an inadequate office budget. & DNI & VLI & SI & GI & DI \\
\hline $\begin{array}{l}\text { 13. conflicts with my Program Unit } \\
\text { Director. }\end{array}$ & DNI & VLI & SI & GI & DI \\
\hline
\end{tabular}




\begin{tabular}{|c|c|c|c|c|c|}
\hline $\begin{array}{l}\text { I left WVU Extension because } \\
\text { of... }\end{array}$ & 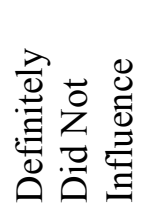 & 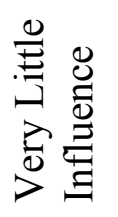 & 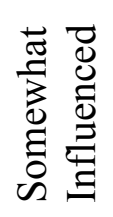 & 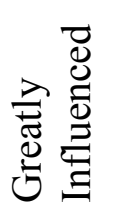 & 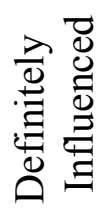 \\
\hline $\begin{array}{l}\text { 14. lack of feedback regarding my } \\
\text { performance. }\end{array}$ & DNI & VLI & SI & GI & DI \\
\hline $\begin{array}{l}\text { 15. a lack of support from on-campus } \\
\text { faculty and staff. }\end{array}$ & DNI & VLI & SI & GI & DI \\
\hline $\begin{array}{l}\text { 16. not being adequately prepared for the } \\
\text { promotion and tenure process. }\end{array}$ & DNI & VLI & SI & GI & DI \\
\hline 17. changing administrative policies. & DNI & VLI & SI & GI & DI \\
\hline 18. conflicts with my co-workers. & DNI & VLI & SI & GI & DI \\
\hline $\begin{array}{l}\text { 19. a lack of time for professional } \\
\text { development. }\end{array}$ & DNI & VLI & SI & GI & DI \\
\hline 20. insufficient funding for programs. & DNI & VLI & SI & GI & DI \\
\hline $\begin{array}{l}\text { 21. the promotion and tenure process was } \\
\text { not fair and equitable. }\end{array}$ & DNI & VLI & SI & GI & DI \\
\hline 22. Other: (Write in) & DNI & VLI & SI & GI & DI \\
\hline
\end{tabular}


Job Related Factors

\begin{tabular}{|c|c|c|c|c|c|}
\hline I left WVU Extension because..... & 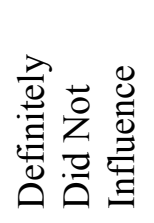 & 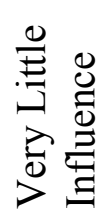 & 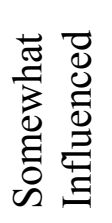 & 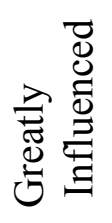 & 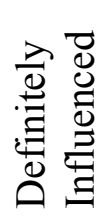 \\
\hline 23. my work was not interesting. & DNI & VLI & SI & GI & DI \\
\hline 24. my work was not challenging. & DNI & VLI & SI & GI & DI \\
\hline $\begin{array}{l}\text { 25. I did not have opportunities to be } \\
\text { creative. }\end{array}$ & DNI & VLI & SI & GI & DI \\
\hline 26. I was over qualified for my position. & DNI & VLI & SI & GI & DI \\
\hline $\begin{array}{l}\text { 27. of too much supervisor oversight or } \\
\text { direction }\end{array}$ & DNI & VLI & SI & GI & DI \\
\hline $\begin{array}{l}\text { 28. I was not involved in the decision } \\
\text { making process. }\end{array}$ & DNI & VLI & SI & GI & DI \\
\hline $\begin{array}{l}\text { 29. overall, I was dissatisfied with my } \\
\text { work. }\end{array}$ & DNI & VLI & SI & GI & DI \\
\hline 30. I had other priorities in my life. & DNI & VLI & SI & GI & DI \\
\hline $\begin{array}{l}\text { 31. my abilities did not match the } \\
\text { requirements of the job. }\end{array}$ & DNI & VLI & SI & GI & DI \\
\hline 32. my work lacked self-directing freedom. & DNI & VLI & SI & GI & DI \\
\hline 33. of unclear job responsibilities. & DNI & VLI & SI & GI & DI \\
\hline $\begin{array}{l}\text { 34. excessive night, weekend or overnight } \\
\text { commitments. }\end{array}$ & DNI & VLI & SI & GI & DI \\
\hline
\end{tabular}




\begin{tabular}{|c|c|c|c|c|c|}
\hline I left WVU Extension because..... & 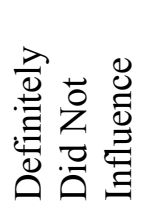 & 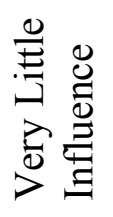 & 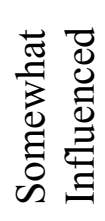 & 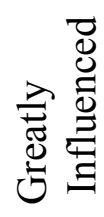 & 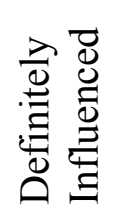 \\
\hline $\begin{array}{l}\text { 35. the values of the organization and } \\
\text { personal values were in conflict. }\end{array}$ & DNI & VLI & SI & GI & DI \\
\hline $\begin{array}{l}\text { 36. no matter how much I did, it was never } \\
\text { enough. }\end{array}$ & DNI & VLI & SI & GI & DI \\
\hline $\begin{array}{l}\text { 37. I was dissatisfied with the distance I } \\
\text { had to travel to in-service training } \\
\text { opportunities. }\end{array}$ & DNI & VLI & SI & GI & DI \\
\hline $\begin{array}{l}\text { 38. of not having enough oversight from } \\
\text { my supervisor. }\end{array}$ & DNI & VLI & SI & GI & DI \\
\hline 39. the nature of the job. & DNI & VLI & SI & GI & DI \\
\hline 40. Other: (Write in) & DNI & VLI & SI & GI & DI \\
\hline
\end{tabular}

Please take a moment to leave any comments on Job Related Factors that influenced you to leave: 


\begin{tabular}{|c|c|c|c|c|c|}
\hline I left WVU Extension because...... & 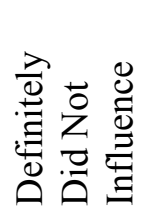 & 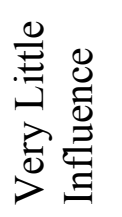 & 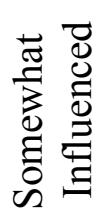 & 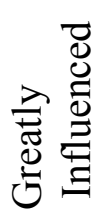 & 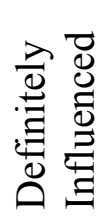 \\
\hline $\begin{array}{l}\text { 41. of inadequate educational } \\
\text { opportunities for myself. }\end{array}$ & DNI & VLI & SI & GI & DI \\
\hline 42. of family obligations. & DNI & VLI & SI & GI & DI \\
\hline 43. of another person's career move. & DNI & VLI & SI & GI & DI \\
\hline $\begin{array}{l}\text { 44. of inadequate educational } \\
\text { opportunities for other members of } \\
\text { my family. }\end{array}$ & DNI & VLI & SI & GI & DI \\
\hline $\begin{array}{l}\text { 45. my work conflicted with my personal } \\
\text { responsibilities. }\end{array}$ & DNI & VLI & SI & GI & DI \\
\hline $\begin{array}{l}\text { 46. I was dissatisfied with my work } \\
\text { location's distance from family and } \\
\text { friends. }\end{array}$ & DNI & VLI & SI & GI & DI \\
\hline $\begin{array}{l}\text { 47. I did not have enough time for } \\
\text { developing personal relationships. }\end{array}$ & DNI & VLI & SI & GI & DI \\
\hline 48. I received another job offer. & DNI & VLI & SI & GI & DI \\
\hline $\begin{array}{l}\text { 49. I decided that this kind of work was } \\
\text { not for me. }\end{array}$ & DNI & VLI & SI & GI & DI \\
\hline $\begin{array}{l}\text { 50. I was attracted to more money } \\
\text { elsewhere. }\end{array}$ & DNI & VLI & SI & GI & DI \\
\hline 51. I wanted to continue my education. & DNI & VLI & SI & GI & DI \\
\hline
\end{tabular}




\begin{tabular}{|c|c|c|c|c|c|}
\hline I left WVU Extension because...... & 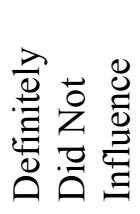 & 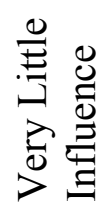 & 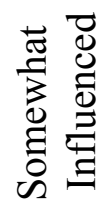 & 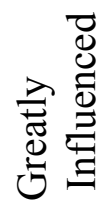 & 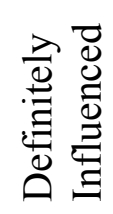 \\
\hline $\begin{array}{l}\text { 52. of a desire to spend more time with } \\
\text { my family. }\end{array}$ & DNI & VLI & SI & GI & DI \\
\hline $\begin{array}{l}\text { 53. I did not have enough time for } \\
\text { maintaining personal relationships. }\end{array}$ & DNI & VLI & SI & GI & DI \\
\hline 54. to do more meaningful work. & DNI & VLI & SI & GI & DI \\
\hline 55. Other: (Write in) & DNI & VLI & SI & GI & DI \\
\hline
\end{tabular}

Please comment on Personal Factors that influenced you to leave: 
For the following section, please choose the most appropriate answer by selection one (1) option.

56. Are you a native of West Virginia?

a. Yes

b. No

57. What is your gender?

a. Female

b. Male

58. At the time of leaving Extension, what was your age?

a. $20-24$

b. $25-29$

c. $30-34$

d. 35-39

e. $40-44$

f. $45-49$

g. $50-54$

h. $55-59$

i. $60+$

59. How many years were spent as an Extension Agent?

a. 0-2 years

b. 3-5 years

c. 6-8 years

d. 9-11 years

e. $12+$ years

60. Which area of Extension were you employed?

a. Agriculture and Natural Resource

b. Community Economic Workforce Development

c. Families \& Health

d. 4-H and Youth Development

e. Other:

(Please Specify Position)

61. Was Extension your first full-time job out of college?
a. Yes

b. No 
62. Was Extension your first career choice?

a. Yes

b. No

63. Which district where you employed in? (select an option that has been offered)

a. Pendleton, Grant, Hardy, Mineral, Hampshire, Morgan, Berkeley, Jefferson

b. Randolph, Tucker, Preston, Monongalia, Marion, Taylor, Barbour, Upshur

c. Hancock, Brooke, Ohio, Marshall, Wetzel, Tyler, Doddridge, Harrison

d. Pleasants, Wood, Ritchie, Jackson, Wirt, Roane, Calhoun, Gilmer, Lewis

e. Mason, Cabell, Putnam, Kanawha, Wayne, Lincoln, Boone,

f. Braxton, Clay, Nicolas, Webster, Pocahontas, Fayette, Greenbrier

g. Mingo, Logan, Wyoming, McDowell, Mercer, Raleigh, Summers, Monroe

64. At the time of leaving, what was your relationship status?

a. Single

b. In a committed relationship

c. Married

d. Divorced

65. At the time of leaving, how many children did you have in your household?

a. 0

b. 1-2

c. 3-4

d. $5+$ 
66. What was your main reason for leaving Extension?

67. Are there changes that could have been made to prevent you from leaving the Extension Service?

68. Please write any additional information that you believe will be valuable to this study. 
VITA

Education: $\quad$ WEST VIRGINIA UNIVERSITY, Morgantown, WV 26506. Pursuing a Master of Science in Agricultural and Extension Education.

Graduated May 2015.

WEST VIRGINIA UNIVERSITY, Morgantown, WV 26506. Bachelor of Science in Agriculture in Agricultural and Extension Education.

Graduated May 2013.

POTOMAC STATE COLLEGE OF WVU Keyser, WV 26726. Associates Degree in Agriculture and Environmental Education. Graduated: May 2011.

Professional Graduate Teaching Assistant, West Virginia University, Experience: Morgantown, WV

Program Assistant, West Virginia University Extension ServiceJefferson County.

Student Teacher, Jefferson High School Shenandoah Junction, WV 25442.

Extension Camping Instructor, West Virginia University Morgantown, WV 